Portland State University

PDXScholar

1975

\title{
Freedom and Necessity in the Development of Marx's Thought
}

Isa Maria Leib

Portland State University

Follow this and additional works at: https://pdxscholar.library.pdx.edu/open_access_etds

Part of the European History Commons

Let us know how access to this document benefits you.

\section{Recommended Citation}

Leib, Isa Maria, "Freedom and Necessity in the Development of Marx's Thought" (1975). Dissertations and Theses. Paper 2290.

https://doi.org/10.15760/etd.2287

This Thesis is brought to you for free and open access. It has been accepted for inclusion in Dissertations and Theses by an authorized administrator of PDXScholar. Please contact us if we can make this document more accessible: pdxscholar@pdx.edu. 
AN ABSTRACT OF THE THESIS OF Isa Marla Leib for the Master of Arts in History presented May 16, 1975:

Title: Freedom and Necessity in the Development of Marx's Thought.

APPROVED BY THE MEMBERS OF THE THESIS COMMITTEE:

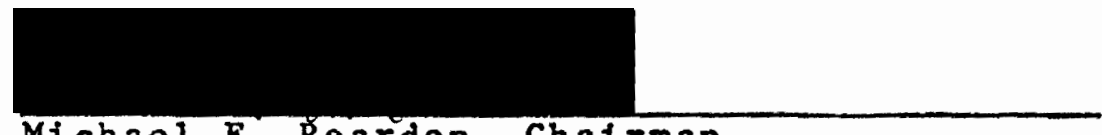

Michael F. Reardon, Chalrman
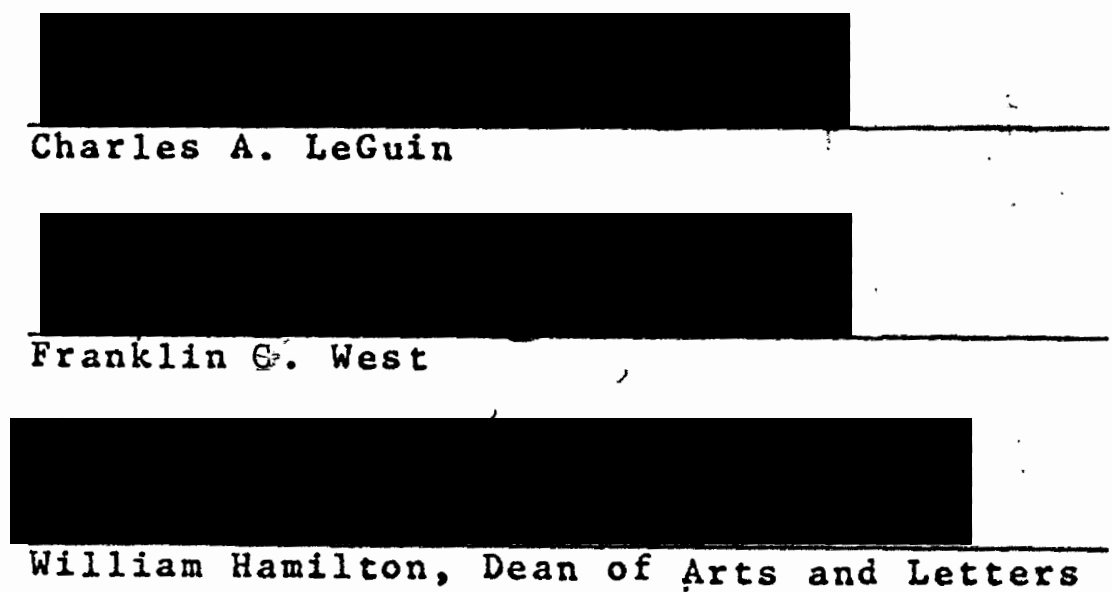

Following a suggestion of Dr. Michael Reardon's I have considered Freedom and Necessity as fundamental literary and philosophical concepts in Karl Marx's early writing.

All Marx quotations are my own translations; I did this because I discovered that many English translations were rendered in such a way that they did not convey basic literary structures which were very important to a clear comprehension of Marx's thought.

For example: In a passage from the Economic and 
Ph1losophical Manuscripts of 1844, Martin Milifgan substituted the English "treat" for the German "relate", exchanged "confirmation", In a religious sense, Into "proves himself". Within the structure of the paragraph, with 1ts images of transformation and metaphors of cultivation, I really did not think that Milligan's transiation sald the same thing that Marx said.

Another example can be cited from the same passage: In discussing the natural species- or family-being of mankind, In the sense of blology and blological needs, Marx. consistently constructs a "cultivation" and "husbandry" : metaphor. This metaphor, in Milligan's rendering, ceased to exist at all, as he exchanged "creating" (of the objective world) for Marx's literal "cultivation" of that world. Indeed, there is a considerable difference of meaning between "to create", which is a godlike power, and "to cultivate", which is a most fundamental attribute of civilization, of man's labor. "Procreation", as the first historical act, also vanishes as itself, and is turned into "creation", which is quite another matter altogether. What is lost by that substitution is the meaning of the primal activity of procreation and reproduction by and of animals and men, the natural being of humanity in a natural, objective world. This perhaps appears as mere critic's hair-splitting, but in point of fact, a more careful observance of the literature Itself will go a great distance toward the 
maintenance of the logic and coherence of a sentence or passage. Within the literary structures one finds the heart of Marx's meaning, and the process of critical interpretation 1s thexeln observed.

It must be stated here that any translation from one language to another is certain to lose something of its native architectural character and structure, and is also likely to have something of the preferences and prejudices of the translator impressed upon it. Even so, keeping the dangers in mind, it is desirable and possible, and necessary, too, to embark upon such perilous waters as these. It is possible to keep the English meaning literally and Iiterarily close to the German, and to remain acceptable, even elegant, as English, though the vocabularies will not in all cases correspond exactly one to the other.

The opening pages of this article are a necessary but brief discussion of words, which are specifically: Necessity, Freedom, and History. As these three words are the Iife and breath of Marx's thought, an observation of their meanings and hiscory, in German, was the obvious place to begin in a consideration of the development of Marx's ideas.

The Marx quotations, and most of the Heine, are for the abovementioned reasons, my own translations. I have labored to present them according to their own words. No poetic liberties were allowed or taken. Where there may be a question or doubt about a particular word or phrase, I have included Marx's own German words in parentheses. 


\title{
FREEDOM AND NECESSITY IN THE DEVELOPMENT \\ OF MARX'S THOUGHT
}

by

ISA MARIA LEIB

\begin{abstract}
A chesis submitted in partial fulfiliment of the requirements for the degree of
\end{abstract}

\section{MASTER OF ARTS \\ in \\ HISTORY}

\author{
Portland State University \\ 1975
}


TO THE OFFICE OF GRADUATE STUDIES AND RESEARCH:

The members of the Committee approve the thesis of Isa Maria Leib presented May 16, 1975 :
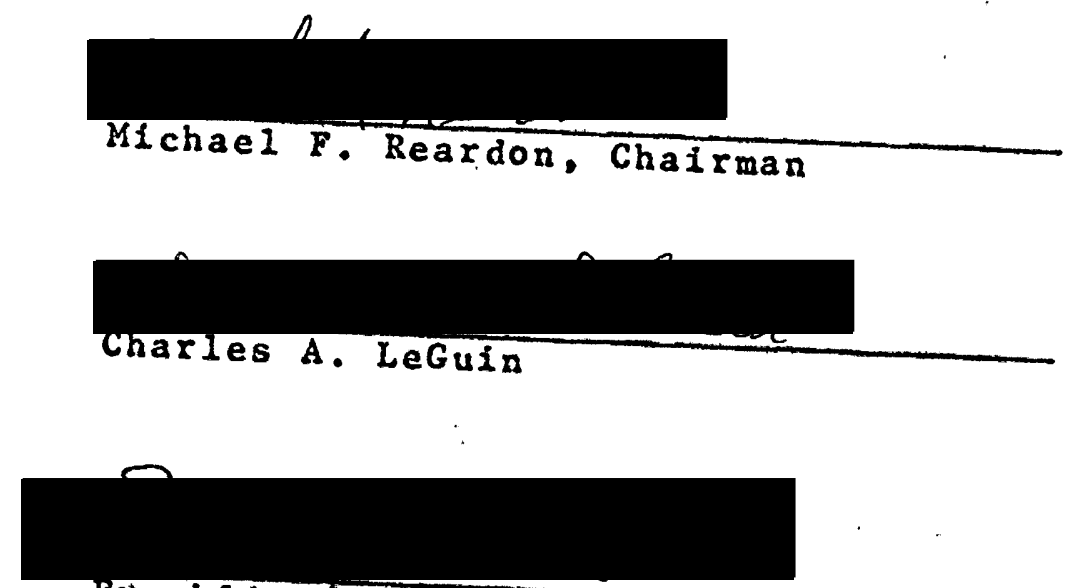

Franklin te. West

\section{APPROVED:}

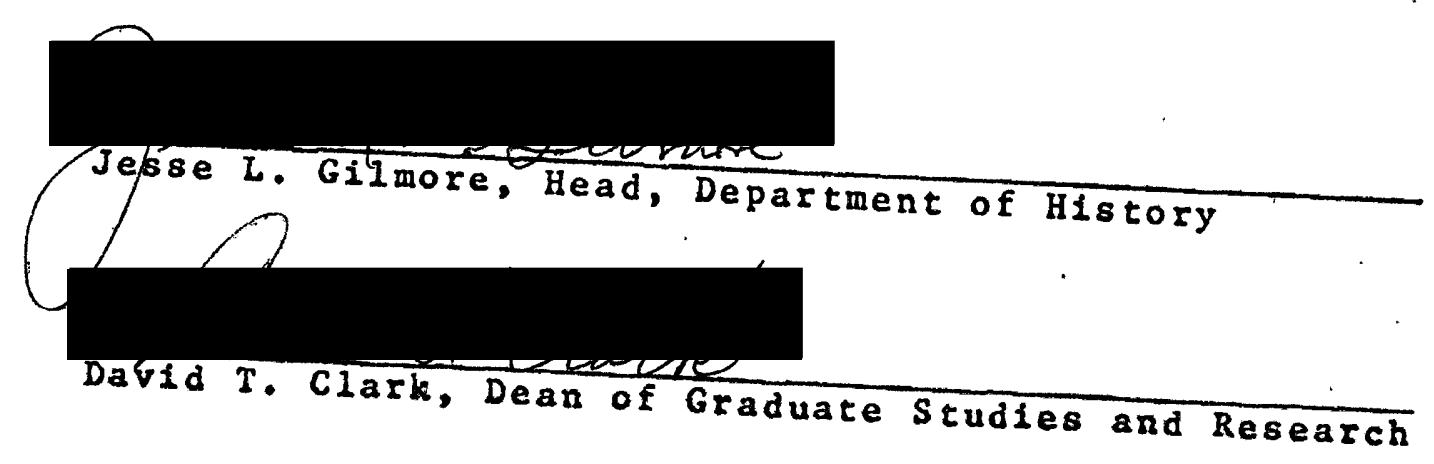

May 23,1975 


\title{
ACKNOWLEDGEMENTS
}

My deepest thanks for so much help and comfort during the work on this paper go to:

\author{
Mother and Father \\ Michae1 Reardon \\ Carol Wood \\ George Stevens \\ Elaine Steinke \\ Rachael Ruth \\ Ludwig van Beethoven \\ and most especially to: \\ Karl Marx.
}


TABLE OF CONTENTS

PAGE

ACKNOWLEDGEMENTS

i11

LIST OF FIGURES

$\mathbf{v}$

PART

I PRELUDE AND BRIEF HISTORY OF THE THESIS . . . i

i "language lesson" . . . . . . . . . . 6

II MODERN GERMAN HISTORY . . . . . . . . 10

IV HEINE . . . . . . . . . . . . . 28

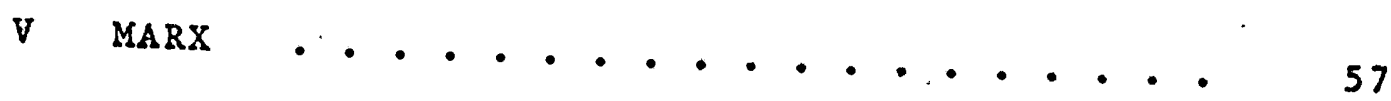

VI FINALE: ALLEGRO MA NON TROPPO ...... 73

SELECTED BIBLIOGRAPHY . . . . . . . . . . . 79

APPENDICES 


\section{LIST OF FIGURES}

FIGURE

PAGE

1 Necessity as the Basis of Freedom . . 70

2 Schema of Communism equals Humanity . . 72 


\section{PRELUDE AND BRIEF HISTORY \\ OF THE THESIS}

Sometime during the progress of the seminar on the development of Karl Marx's thought, Michael Reardon recommended that I do a "Iinguistic analysis" of Maxx. I did not immediately respond to the suggestion, not being entirely certain what was meant by "Iinguistic analysis"; also, I was not too sure that I was the "man" for the job. But: While reading a particular passage in the Economic and Philosophical Manuscripts of 1844, published in Robert $C$. Tucker's book, The Marx-Engels Reader, translated by Martin Milligan, I grew skeptical of what I was reading. I am not quite sure at what moment I was aware of my own suspicion, but some break in the literary "flow", some slightly "off" tone in the metaphor, or worse, the mixing of metaphor. (throughout the translated text), caused me to track down a copy of Marx's own German, and to see for myself what were Marx's own words, though, as Marc Bloch so ably stated, the word is equivocal.

The difference between my translation, crude and it:eral as 1 t was after a first rendering, and the Milligan translation was astonlshing, and I really did not know what 
to do. Though technically not a lingulst, and though my

German is not at all expert, I thought that, in the interest of science, I could after all proceed on an analysis of the language--tone, color, metaphor, imagery--of Marx's thinking and writing. Some particularly striking influences upon that diction were Marx's knowledge of Shakespeare (Schlegel's translation), his thorough knowledge of Greek literature and philosophy, in Greek (see for Instance his doctoral dissertation and attached notes: Ober die Differenz der Demokritischen und Epikureischen Naturphilosophie); his widely varied reading and comprehension of music and art. These revealed themselves very clearly in Marx's own language.

The discrepancies in the one instance, which is cited in the rext of this thesis, were soon to be found in other cases, and my over-riding thought was why this should be so. With the German text in front of me, pen in right hand, Oxford German dictionary in my left, I proceeded to translate, and had to wonder why, in some cases, a particular English word would be substituted for a primary-meaning word, especially when the primary meaning, moving from German to English, conveyed quite nicely the intent or direction of the German original, and which stayed well within the context of a particular metaphor.

For example, in the passage cited on page 63 of this thesis, Miligan substitutes the English "treat" for the German "relate" (yerhält), and changes "confirmation of the human being" (confirmation in a rellgious sense, die 
Bewährung) into "proves himself". Within the paragraph as a whole, I. really did not think that they.said the same thing, or gave the same message. Another example is to be found in the same passage: Marx, discussing the natural species or family-being of humanity, constructs throughout a "husbandry" and "cultivation" metaphor, which metaphor is badly scrambled by Milifgan's substitution of "creating" for "cultivation" (Bearbeitung) of the objective world, the "cultivation" being in fact the "confirmation" of that world, and of the humanity of man. Milligan also exchanged the "husbandry" metaphor for something much harder to discern or identify by exchanging "In creating an objective world" for Marx's original "The practical production (the third synonymn, following "begetting" and "procreation" for Erzeugnung) of an objective world." Indeed, the primary or primal activity of procreation and reproduction by and of animals and men is the point of the paragraph, and this point is not at all clear in Milligan's rendition.

Perhaps this appears to be only a critic's hairsplitting, but in point of fact, a more careful consideration of the literature will retain the natural and internal logic of a particular sentence or passage, and with that, its meaning, which is to be discovered by the process of critical interpretation. And granted, any translation from one 1anguage to another is certaln to lose something of 1 ts true architectural character and structure, and is likewise likely 
to have something of the character and preferences of the translator stamped upon 1t. Nevertheless, keeping the dangers in mind, it is desirable and possible to embark upon such dangerous waters as these, and attempt to keep the English meaning literally close to the German and remain acceptable as English, even though the vocabulary will not always correspond exactly one to the other.

The inftial pages in the article, which are a necessary but brief discusston of word meanings--spectfically: Necessity, Freedom, and History--provide some detalls and history about the words which are the heart and soul of Marx's writing. It also seemed to be the most obvious place to begin in considering the development of Marx's thought.

All of the Marx citations, and most of the Heine, are my translations, and I have endeavored to present Marx and Heine according to their own words. No poetic liberties were allowed or taken. It is worth saying that I think that Marx wrote with a certain relish in his task, and with a crisp and ironic humor. Where there may be a question or some doubt about a particular word or phrase, I have included Marx's own German words in parentheses. (See Appendix D for these sources) 
I think well of all skepticism to which I may reply: 'Let us try it'. But I no longer want to hear anything of all those things and questions which do not permit experiments. This is the limit of my 'sense of truth'; for there courage has lost its rights.

Nietzsche 
PART II

"LANGUAGE LESSON"

Since the most difficult thing to know is where to begin, we shall begin with the most obvious, that being to discuss the words "freedom" and "necessity", and what these words meant in the German that Karl Marx wrote and spoke.

The word Libertaet meant originally the rights of the German princes within the Holy Roman Empire; these were primarily political and civil rights or privileges such as taxation and military expansion and maintenance, which were an outgrowth of the increasing powers of the aristocracy in feudal Germany. Leonard Krieger suggests, in The German Idea of Freedom, that these various political rights and freedoms of princes have a greater meaning in any consideration of the German notion of freedom than do the categorical, theological divisions of the spirit and the Flesh. The freedom versus determinism (or necessity) dichotomy of orthodox Lutheranism plays less of a rôle in German philosophical and political development than the old Imperial Libertaeten. (Krieger, 1957, pp. 6-7) During the course of the late 18 th century down to the last generation of the $19 t h$, the internal connection and frictions between the governing rights of princes and the 
representative rights of bürgers and peasants were gradually associated with individualized freedom or liberty, or lack of it, with the authority of the state, and especially with the authority of the prince. Marx said of Libertaet:

- - the human right of Freedom is not based on the unfor of man with man, but rather on the separation of man from man. It is the right of this separation, the right to limit or restrict that individuals conflne or limit to themselves. (Marx 1962, p. 473; Tuckex 1972, p. 40) (author's translation)

A second word, die Freiheit, also means freedom, but it connotes a much more internalized or personalized concept of this human condition. It is also a rather more modern or romantic idea of inner freedom which gained much momentum during the course of the 19 th century. It was to become associated with artistic andintellectual freedom, and played a significant role in the works and lives of 19 th century literati.

"Necessity" is not really a German word. It is the usual English translation for a number of words with related but slightly varied meanings and usages. Some of these are: die Not, a noun which is generally used to convey a situation of distress, or want, or need; a verb, nötigen, meaning to force, to urge, or to compel; die Nötigung, a gerundical noun, implies also a condition of compulsion or forcing; die Notwendigkeit likewise has the root of need, often translated as necessicy. Marx variously used the forms of the word, das Bedüfnis, from the verb 
düfen, which means to have need of, or to be in need of. There are two other words which it would be well to consider here in the discussion of Marx's usages. These are two words for history. The usual German word, die Geschichte, is derived from the verb geschehen, which means to happen, or to occur, or to be done. Another noun arising from this is das Geschehen, which means a story, happening, or event. The Greek word, historein, of which Marx was fully cognizant, means literally to inquire or to investigate, or to research something. It is also connotative of a natural or organic process, and tends to carry with it the notton of Gestalt, which in the German is Form. Marx uses the word Geschichte in his writing, and appears to have merged the older Greek idea of Iinear, everyday occurrences with the German study of phenomenal events current in Enlightenment Germany. (Löwith, 1967, p. 212)

In defining history as a march of natural, inevitable processes, Marx finally fused the apparent dualism of freedom versus necessity in a critical method usually referred to as "dialectical materialism". A kind of "theology" of romantic humanism underlies his view of historical man; the axiom is that history, considered in massively human terms, 1.e., group or class, or national terms, exhibits certain patterns or tendencies, which are discoverable, by means of the dialectical method, and plainly operative in the course of historical events. Thereby, Marx proceeds to expose and hold up for 
public gaze the needtul, raw economlc basis of the general human struggle, which is material, of this world, and which Is the history of life in this world.

It is therefore the task of history, after the truth of the world to come has faded, to establish the truth of this world. It is above all the duty of philosophy, which stands in the service of history, after the sanctification of human self-estrangement (entfremdung) has been uninasked, to unmask self-alienation in its unholy forms. With that, the criticism of Heaven cransforms Itself into a criticism of Earth, the criticism of religion into the criticism of right, the criticism of theology into the criticism of polltics. (Marx, 1844, p. 489, and Tucker, 1962, p. 12) (author's translation)

Theological considerations, for Marx, no longer had a place in what were properly human considerations; the proper study of man is man, and history is the rightful study of man, or, rather of men and women, a "science", though somewhat Inexact, of human beings struggling with and against each other. These political, blological, and economic struggles are, in Marx, the soul of history. Though history is a study also of mass, or masses, as guilds, or classes, or nations, these nonetheless tend to assume individualistic characteristics when they are historlcally examined, at least for the convenience of examination and argument. 
PART III

\section{MODERN GERMAN HISTORY}

Modern German history in fact begins in 1789 ; there are two respects in which this is so: 1) men and women became prey to polftical conflicts, fears and hopes; 2) the German people began to consider themselves "modern", i.e., they thought of themselves as very different from their parents and grandparents. (Mann, 1970, p. 19) The late 18 th century was typified by a hopefulness for the future among politically-minded Germans that was not evident before. Thinkers held the existing political institutions in low regard, considering the old medievalisms an "incomprehensible aberration". (Kant, quoted in Mann, p. 19).

Economic 1 ife throughout the 1,789 German-speaking nations (Mann, p. 6) was, as it had been for centuries, agrarian. Weimar, Baden, Brunswick, Bavarta, Dessau, Hesse were parts of the remainder of the old Imperium which included in fts system of principalities the two powers, Catholic Hapsburg Austria in the south, and Lutheran Prussia, itself a loose collection of territories in the north and east. (Mann, p. 8) Deutschtum im Ausland, Germans who lived abroad, were those who lived at the fringes of the old Holy Roman Empire, in Poland, Czechoslovakia, Hungary, and Italy. (Mann, p. 8) "Germany" was in fact multi-nationally European. (Mann, p. 13) 
The Aufklärung had left this fossilized and somewhat comic old Empire virtually untouched until 1789, and its representatives were largely the respected professors, intellectuals, and writers of cötingen and Berlin; they were not the pol1rically restless who populated the revolutionary brigades of France. (Mann, 1970, p. 17)

At the close of the $18 \mathrm{th}$ century, serfdom was still extant in most of these German countries. Peasants were as bound to the land of their lords as they had been in the M1ddle Ages. In 1788, a peasant could not leave the estate; if he tried to escape, he was tracked down and brought into custody. Jurisdiction was solely the lord's right, Libertaet, and a close watch was kept on all private affalrs of the serfs, who stood to be punished for idleness or intemperance. (de Tocqueville, 1958, p. 5). Peasants in the German-speaking cantons at the time of the French Revolution rarely owned land, nor could they hope to much improve their status through either marriage or changes in occupation. The equivalent of the French corvée, or system of forced labor, was in full flower; landless peasants maintained the prince's or margrave's grounds and buildings, drove his carriages, and cared for his horses, transported his goods and produce to market. (de Tocquevilie, p. 5).

What few freedoms and privileges there were for the nonnoble existed chiefly along the River Rhein. Here, the German peasant enjoyed almost as much liberty, including ownership 
of land and animals, as did his French counterpart; and it was especialiy in the Rheinland that zeal for the ideals of the French Revolution ran the highest. (de Tocqueville 1958, p. 7) Intellectuals (Intellektueller) and politically thoughtful people had been developing a political formula for nearly fifty years, and this had at its heart the notion of individual human freedom. The ocoupation of the Rheinland by a crusading, revolutionary army (Napoleon's) certainly accelerated the procedure of liberal and national tendencies which had taken root during the Aufklärung of the 18 th century. (Krieger, $1957, p \cdot 139)$

Even so, the majority of the German population continued in hard labor on the land; forests were large and thick, roads were few and notorlously bad (Mann 1970, p. 19). There were few wealthy merchants and aristocrats, and these were chiefly to be found in the old free cities on the Rhein, as Frankfurt and Hamburg. There were also government officials and burgers, but it remained to the peasants to produce all the necessities for German 1ife. Industry, as it was advancing In England, was as yet in its cradle; there was no prosperous, liberty-conscious bourgeoisie, no powerful Third Estate as it existed in France; by comparison, the German middle class was small and very weak. The old trade centers, such as Nïrnberg and Augsburg, no longer flourished and bustled as they had during the days of the Renaissance. In fact, cities and towns were quite smali and quiet, and had 
not grown substantially since the 17 th century. (Mann 1970 , p. 19).

The steady rise of the north and eastern section-Prussia-Weimar--and the process leading to it is perhaps the most blgniflcant "German" event of the $18 \mathrm{th}$ century, and $1 \mathrm{t}$ gave a modern national shape to Germany. (Mann, p. 13). Frederick the Great brought Prussia Into being after his Silesian wars; his Junkers--privileged land holders--became the masters in Mecklenburg, and, under the patronage of the Tsar, masters of the Russian Baltic provinces as well (Mann, p. 14); that 1s, they mastered Poland. The Elector of Hanover was away, occupying the English throne, and the Junkers ruled his electorate in his stead.

The great Frederick aliowed no aristocratic influence in Prussia--there the Junkers worked and fought only for Frederick; if they desired a princely life, they sought it elsewhere. (Mann, p. 14) Junkers were not the masters of Prussia; that distinction belonged exclusively to Federick II. Only in the countryside did nobles exercise any authority; their privileges extended to jurisdiction over peasants and monopolization of the senior offices of the army, which itself represented Frederick's greatest expense. (Mann, p. 15)

Frederick's reign, for all its astringent extremism, was nonetheless, in its time, considered enlightened and progressive, not at all reactionary. A stern, professional, working monarch conducted his state's interests in an efficlent 
and business-ijke fashion, and with the means of an equally competent bureaucracy. This "philosopher-king" and man of French letters, who had transformed scattered parcels of territory into a European power, earned the respect of Europe; he was taken quite seriously, though the center of the German nation was still vienna, and not yet Beriin. (Mana 1970, p. 15)

His alliance with Britain assured backward, provincial Prussia's emergence, without threat, into the arena of world politics, and Frederick II tolerated, or at any rate permitted, all freedom of thought that was not political. There was freedom in Germany; whatever could not be sald or done in one state could be sald or done in another, and that was usually within a day's ride. (Mann, p. 16) For the most part, the existing political system in Germany, with the one exception of Prussia, was unchanged since its establishment by the treaties of Westphalia of 1648 , though in the $1870^{\prime} \mathrm{s}$ and $1880^{\prime} \mathrm{s}$, a new spirit rose in the land which was transcending, or transforming the old, medieval forms. $($ Mann, p. 16)

Das Jahrhundert ist im Sturm geschieden Und das neue öffnet sich mit Mord... Schiller

For such a phenomenum in human history can never be forgotten, because it has revealed a trait and a capacity in human nature which no statesman could have gleaned from the previous course of things and which alone unites nature and freedom according to internal principles of law in human history. (Kant, quoted in Krieger 1957, p. 104)

Referring to the pressures of the "pre-reform" period 
of 1797-1806, the Prussian minister Carl August von Struensee remarked that "the king is a democrat in his way; he works constantiy for the limitation of the nobles' privileges.." (Krieger 1957, p. 146) Nonetheless, the movement of the old to tho new time required the otunning defeat of the Junkers at Jena. Following this devastation, Libertaet assumed a fresh meaning, that of the princes' rights to reform their own states, with, of course, the aid and consent of an enlightened and central monarch. The nobles who came to the fore after Jena were for the most part progressively minded; they did include in their policies a formulation of individualistic, though princely, freedom. It is well to keep in mind that", ... the monarchical state was the central core of public life, the agency of freedom as well as of order. Men who wanted to increase the measure of their Iiberty would be driven either to compromise with the existing authortties as the only possible advocates of their claims or to move toward radical renunciation or revolution as the only possible forms of freedom not already claimed by the state." (Krieger, p. 8I)

With this, in 1806, German nobles undertook. the task of reformin Prussia; as landed and titled aristocrats, these liberally-minded men necessarily qualified the revolutionary ideal of popular freedom with a social context that remained nevertheless hierarchical. This, they insisted, was the only course compatible with an suthoritarian, i.e., 
a strong state; as that state's officials, they understandably trimmed the French ideal of liberté of any traces of the popular "right" of guillotining of kings and princes. (Krieger 1957, pp. 146-147)

- What the state demands from us as a duty is eo ipso our rights as individuals, since the state is nothing but the articulation of the concept of freedom. . . The state is the one and only prerequisite of the attainment of particular ends and welfare. (Hegel, quoted in Krieger, p. 81)

In considering freedom, the starting-point must not be. - . the single self-consciousness, but only the essence of self-consciousness; for whether man knows it or not, this essence is externally realized as a self-substitent power in which single individuals are only moments... . The basis of the state is the power of reason actualizing itself as will. (Hegel, quoted in Krieger, p. 483)

The alternatives to Erederick the Great's reforms, initiated under the aegis of "enlightened" absolutism which included censorship of writings and all publishable communications, were those reconciliations between (state) authority and individual or civic liberties which were to be found in aesthetic discourse, religious pietism, or in endless tracts, highly idealized, touting the various aspects of medieval culture (Volkskultur).

The natural law school which dominated late 18 th century thinking and which defined freedom in terms only of Libertaet transferred the formerly exclusive princely rights and privileges to a broader consideration of society as state. Fichte's ideals of freedom revealed themselves in a frankly authoritarIan framework which flatly denied the existence of any "natural law" outside the state--the nationally-minded (Prusstan) state 
had the "perfect right" to

- - Ifmtt the natural freedom of the individual as much as possible; freedom exists only for the higher national purpose lying beyond the state and only when the state is governed by the national point of view does it expand itself to include 1iberty as its end. (Fichte, quoted in Krieger 1957, p. 19.1)

Nationalism; as volced by Fichte, was beginning to replace the defunct Empire as the frame of reference; it alao made emphatic what had been merely implicit in the old Imperial confederation of authorities, $1 . e$. it Included the "free individual citizen and his values in the naclonally sanctioned claim of the state" as "the highest earthly organ of human Ereedom". (Krieger, p. 191)

As the state is the form in which the individuals of a ruling class maintain (geltendmachen) 1 their common interests and in which the entire clvil (bürgerliche) society of an epoch is summed up, it follows that all common institutions become obtained through the state, receiving a political form. Hence the lliusion that Law is based upon the will, indeed upon that from which it is separated, its real basis, the free will. (freien Hillen). Just so, Right (or Justice: Recht) then is reduced to the 1aw. (Marx 1846, P. 93; Tucker 1972, P. 151)

Throughout the period of the French Revolution and NapoIeonic wars, Germany was surprisingly quiet; though greatly interested in French affairs, Germans watched more or less passively as the duel raged between France and England. By 1807, Prussia and Austria had "adapted" themselves to the winds of change, their officials believing that they would eventually

${ }^{1}$ Note: may also mean "to plead", gelten, meaning "to have influence" or "to matcer, mean". 
blow away. (Mann 1970, pp. 21-22) Some traditions altered, political frontiers shifted and changed; some laws changed as a result of events elsewhere in Europe. Only at the end--in 1813--did Germans rouse themselves against the mighty armies of France, having realized, following the terrible defeats of Austrians and Prussians, that something had happened which. forever altered the face of Europe. The convulsive death of the ancien régime in France trumpeted, in short, the end of the old way in aII of Europe.

The whole of the continent, England included, was at war with France. Napoleon's modern war machine implemented such innovations as mass national armies, long fronts, and devastatingly swift strike-power. (Mann, p. 24). Again and again, from 1792 until Napoleon's final defeat at Waterloo, Europe's powers allied themselves against France, but it must be sald that these were marriages of convenience only. In the meantime--from 1807 to 1812--Prussia, Austria and Russia aligned and re-aligned against each other as often as against Napoleon; the smaller German states trusted nefther Prussia nor Austria: In 1795, Prussia withdrew from the Grand Alliance in order to gain ten vital years of "neutral non-participation". (Mann, p. 25) Austria followed the Prussian lead, withdrawing first in 1797, then in 1801, and again in 1805. Russia maneuvered the same hazardous course in 1807. (Mann, p. 25)

These "armistice" periods, the Peace of Iunévilie in 1801, the Peace of Pressburg in 1805, and the Peace of Tilsit in 1807, were, for the most part, times of experiment and 
domestic and political changes, most of which were the direct result of Bonaparte's activities. He played the leading rôle in German history as well as that of France; the shape of Germany's new legal, political and administrative life, instigated by Napoleon, was retained until the last of the 19th century, and in some instances well into the 20th. (Mann, 1970, p. 25) Dissolving the ancient Empire, Napoleon immealately replaced it with a surrogate, the Confederation of the Rhine, and himself was the ruler of the old medieval Reich, the new Charlemagne. (Mann, p. 26)

In Austria, electorates, ecclesiastical states, princebishoprics, monasteries and imperial abbeys were seized and secularized after the French model. One result of this "mediatization" of 1806 was the emergence of stil1-recognizable German states--Bavaria, Baden, Hesse, and Würtemberg. (Mann, p. 26) The old decaying feudalism of the ancient Reich was summarily given its last rites, and politically conscious Germans, what few of them there actually were, recognized these changes as a practical and necessary solution to the old problems. Napoleon did not want a German nation-state to emerge--that would have been too threatenIng and insecure an eastern border; he therefore did not divide the German states between Prussia and Austria, but instead salvaged a few dynasties which he could easily control, as he had done in Italy. (Mann, p. 27) Bavaria became the strongest of what later were called the Mittelstaaten; dialects and customs were radically scrambled 
In these newly-created states, for example, Franconia was administered by Catholic Bavaria, the Palatinate by Baden. The German princes themselves served the Emperor Napoleon handsomely; they were now the legitimate rulers, bearing ancient and respected names, but they were Napoleon's creatures nonetheless. (Mann 1970, pp. 27-28) In order to further weaken Austria and Prussia, Napoleon was careful to make the Mittelstaaten princes the beneficiaries of the partition. Nine years later, the Confederation of the Rhine was to become the German Confederation, a new power which would attempt to emulate past imperial glory, and which symbolized the disappearance and dissolution of the old way. (Mann, p. 29)

There were at least three ways in which the French Revolution changed Germany: 1) The Rhineland, reformed directly from Paris, was ruled by France for twenty years, and the liberal rule was much appreciated by the Rhenish Confederation for its intelifgence and strength. (Mann, p. 29) Though Napoleon's rule was absolute, it nonetheless had replaced the antiquated feudal order with streamined, well-organized administrations. Jew and Gentile, knight, peasant, bürger, whether in Cologne, Bonn, Speyer, Trier, or Mainz, all prospered under the liberal French rule.

2) In the south of Germany--Suddeutschland--the absolutist, bourgeois spirit also flourished. In the surviving states of Baden, Bavaria and Württemberg, schools were administered by government decree, and churches changed into national churches after the Revolutionary model. Class pri- 
vileges were eliminated, and the style of the French départments replaced the old bureaucracies; universities and mintstries were alike renovated, or new ones created altogether. (Mann, p. 30)

3) In 1806, Napoleon destroyed utterly the aged Prussian war machine, easily and completely. Prussia's "neutrality", gained in 1795 by the Treaty of Basle, did nothing to halt this inevitability, especially as Napoleon clearly recognized Prussia as the most dangerous of the Germans. His reorganization of the Prussian system was considerably hampered by the Tsar, who, among other things, labored to keep Poland between himself and the Prussians; but Bonaparte did not further the Tsar's wishes, creating the "Grand Duchy of Warsaw" instead, and promising in future an independent Polish nationstate. This was a most unpopular promise in the eyes of the Romanoff, whose imperial aims included the Baltic territories in his schemes. (Mann, p. 31)

Between French Poland and French Westphalia lay the halved Prussian state which was in itself sufficiently cohesive never to be reconciled to this current condition. Napoleon's bisection of Prussia was an action which ultimately enabled Prussia to reform itself along anti-French lines; Frederick II could wait for the time when he could correct the unwanted division. (Mann, p. 32) Prussians secretly dreamed of the coming war of liberation; the Prussian state existed before the Napoleonic reform and codes, a state which had been placed upon a rational, progressive footing by Hohenzollern absolute rule. The current state of affairs, in 180.7, was viewed as 
temporary as it was 11legal.

Freiherr vom stein began his reforms in Prussia in 1807-08. Born an 1mperial knight, he was first among German patriots; he was attracted by the old estates system, the old privileges and obligations, and was a firm believer in strong governmental control. In this way, vom stein was appreciative both of the medieval corporations and modern, liberal ideas. (Mann, pp. 32-33) Peasants were at last emancipated, though the landlords retained their former police powers; the land was divided and sold in order to compensate for losses of payments and old services. Many thousands of peasants were forced off the land in this way; free-trade advocates called this particular policy Baurnlegen, Iiterally "laying the peasants flat". (Mann, p. 33) These displaced serfs became farm laborers; their children and grandchildren migrated to the growing cities and became urban workers.

Aristocrats retained their old statuses for the most part, and profited nicely by the vom stein reforms also. Enriched by productive property, politically sophisticated and privileged, all occupations were open to them; their advancement was unobstructed. Vom Stein desired above all other things a vital, energetic aristocracy, his model being the English, who, as an aristocracy, were rich and politically responsible. (Mann, p. 33)

Vom Stein also urged urban self-administration through 
elected town councils; this one achievement proved to be the most enduring, and Prussia's newly flourishing towns and cities were admired throughout Europe for their public service and activities. His reforms were ultimately the most successful and worthy of admiration in Berlin and Weimar, which were formerly littlo more than enobbiah joked among the cosmopolitan Viennese; Berlin and Weimar were now veritable intellectual Meccas--Goethe and Schiller commiserated and created in these centers, and attracted the luminaries of Europe to themselves and the newly-democratic cities. In splte of this success, vom stein was frustrated by the failure of his representation reforms to reach the national scale. (Mann 1970, PP. 33-34)

As stated earlier, Germany did not realiy play a leading role in Napoleon's fall, even though the Battle of Leipzig occurred on German soil and German and Austrian armies fought in 1t. In fact, Britain and Russia defeated Napoleon. When Prussia east of the Elbe revolted, both Prussia and Eastern Prussia moved toward the Tsarist camp; the Confederation of the Rhine stayed with Napoleon until the Battle of Leipzig, then meekly joined the victor's forces, "where they were received politely in spite of their sinful past." (Mann, p. 40) The Landwehr, Prussia's powerful, popular army, proved its mettle, and by 1813-14 had gained a new character distinguishable by its patriotic xenophobia, 1.e., Francophobia, symbolized by the newly-created Order of the Iron Cross. (Mann, 
p. 40)

Even so, following Napoleon's crushing and final defeat at Waterloo, which was also Prussia's revenge, many, differences of opinion and alms appeared in 1814. The Landwehr, vom Stein, and diplomats all differed considerably; vom Stein and his adherents wanted a great new German Reich, complete with Emperor and corporative institutions; they also wished to eliminate the Confederation Princes; as well as the princes of Saxony, Bavaria and Württemberg. (Mann 1970, p. 41) Vom Stein's demands also included the return of Alsace and Lorraine to German control.

Opposed to vom stein and his reforms were the diplomats--Prince Metternich and the Prussian Prime Minister, Hardenberg, too; a Reich was undesirable and unfeasible in their views, and they plainly disliked any idea whatsoever of a German revolution. The Congress of Vienna, in 1815 , divided the spoils of Napoleonic Europe; it did not restore it, though the princes returned to their privileged habits and customary thrones. (Mann, p. 41) Austria.ruled in Italy, Prussia gladly assumed the Rhineland and its rich resources, and Russia finally obtained the Polish loot. There was no, nor could there have been any, returning to the conditions of pre-1792. The German states following the Congress of Vienna remained those which Napoleon had created, especially including the creation of the Federation on the Rhine. (Mann, p. 41) This was indeed a well-organized federation, with a 
constitution which took reality into account, and which would preserve and protect the "external and internal safety of Germany". (Mann 1970, p. 42)

The new Federal Diet in Frankfurt--the old free city of medieval Rhenish days--recelved elected representatives and could dictate joint tariff and economic policies, organize defense, and assume judicial systems and authority. A strong, confident Prussia on the Rhine--which by this time had come to be Germany's "sacred river"--was considered by the participants in the Vienna Congress to be the assurance against any new outbreaks of French revolutionary fervor. (Mann, p. 42) The principals regarded their accomplishments as sensible, rational, and permanent, and were satisfied that they had at last brought order out of chaos. (Mann, p. 43)

Another change, unnoticed by most Germans, which emerged after 1815 was the shift of the German center of gravity from Vienna to Berlin. After all, the colors of the victorlous liberators were those of Prussia, not of Austria, and Prussian soldiers had rescued the "sacred Rhine" from the evil French. Yet another outcome of the Congress was the emergence of the two German powers-Austria and Prussia. For both, "success" depended on the existence and continuance of the "German Confederation", and. on the friendly, or at least mutually agreeable, relationship of the two victors. (Mann, p. 43)

If I were to say what I had really been to the Germans in general, and to the young German poets 
in particular, I should say I had been their liberator. (Goethe, quoted in Arnold 1865, p. 108)

Indeed, German hiotory prides itself on 1 to movement, which other folk under historical Heaven have nelther put forth nor ever imitated. Namely, we have shared in the restoration of modern peoples without sharing in their revolutions. We would first restore while other peoples dared a revolution, and second, while other nations suffered a counter-revolution, in the first place because our masters had dread, and in the second, because our masters had no dread. But we--our shepherds have led us only once to the summit in the company of Freedom, and that on the day of her burtal. (Marx, 1843 , p. 490, and Tucker 1972, p. 13)

In his essay, "Shakespeare und kein Ende," written in 1772, Goethe had discussed at length the antithesis of "should do" and "must do", and how in ancient (classical) literature the predominant thesis is the inequity between what men "should do" and what they actually accomplish, and how, in "modern" literature, the disproportion was between what men will to do and what they actually accomplish. "In the one case all appears to be destiny, in the other, freedom." (Goethe, quoted in Löwith 1967, p. 196) Goethe understood with great clarity that the will to freedom and power was the Zeitgeist; indeed, he vigorously asserted that romanticism was a sickness, that the over-weening German love of the mythic past was a clear danger to human freedom in that it was unreal and untrue. "But after all it was only an illusion for us to wish to become inhabitants of Rome or Athens ourselves. Antiquity should only appear to us from a great distance, separated from everything trivial, as completely 
past and gone." (Goethe, quoted in Butler 1958, p. 135)

Once the world was whole, in ancient days and in the Middle Ages, the outward struggling notwithstanding; nevertheless, there was once, a unified world, and it produced whole poets. We will honor these poets and be pleased in them ourselves; but every imitation of their wholeness is a fraud, a falsehood which each healthy eye discovers. (Heine, quoted in Butler 1968, p. 139 (author's translation)

The Young Hegelians emphatically attached this spirit to criticism of the existing order of things, and, on the other hand, prepared themselves for the future, noţ passively awaited or prayed for, but actively willed. The spirit of the present looked optimistically to the future, progressively interpreting the course of history as an: onwardly flowing stream. History itself is transformed into the ultimate arbiter even of the spirit. Marx transformed the chiliastic Zeitgeist of the Epigonen and passion for freedom of the Young Doctors into the "political eschatology" at which dialectical end stands communist man, a collective "species-being" who belongs to the realm of necessity, but lives also beyond it, in the realm of freedom Marx too displayed the romantic epoch maker's consciousiess in his concluding that ultimate freedom is ultimate commun ty (Löwith 1967, p. 243).

IKarl Immermann: A story of the liar, Minchausen, in whom are embodied all"winds of the age"as the incorporation of the Zeitgeist (present), who eagerly anticipates the new age. 


\section{PART IV}

\section{HEINE}

We must now turn to a relationship which intellectually and historically affected Marx's thought about spirit and freedom. We must now turn to a discussion of Heinrtch Heine's influence on Marx.

Heinrich Heine, born in Disseldorf in the Rhineland in December of 1797 , and who lived until 1856, is known in the English-speaking world primarily as the poet whose poems and ballads became Lieder at the keyboards of Schuman, Schubert, and Mendelssohn. We, however, are not so concerned here with his poetry as we are with the sophistication, or the uniqueness of his thoroughly modern awareness of the history of the political and philosophical changes which were occurring throughout Europe. This awareness, evident in Heine's prose works. of the $1830^{\prime} \mathrm{s}$ and $1840^{\prime} \mathrm{s}$, displays itself in numbers of satires, essays, letters, and journals.

He fled to Paris in 1831, in despair of his liberty as well as his freedom; his sensitivity to the peculiar German lack of historical consciousness, and to its political isolation and its consequences, had been displayed in his published material, and this had rendered him highly suspect in the censor's eye. (Sagarra and Tint, 1971, pp. 134-135). His fears were not unfounded. This former student of Hegel's at 
Berlin (1821-23), emulator and admirer of Byron, Jew, and freethinker was well aware of the Junges Deutschland writers who had languished in Prussian forresses. Ruge and Gutskow, friends of Heine's and politically restless, had been Imprisoned by Prince Metternich for their troubles.

$$
\text { Prince Clemens von Metternich, Chancellor of the }
$$

Hapsburg multi-national state, gave to the policy of Congress Europe a "static, frightened, vindictive emphasis". (Mann 1970, pp. 52-53) Austria's leaders were opposed to any further European upheaval, and desired above all a return to the peaceful and familiar old days.

The German Confederation itself was a "miniature Congress Europe"; (Mann, p. 54) led by anti-liberal, unproductive, and non-progressive Austria. The Federal Act of 1818-19, which might have been used to tackle Germany's economic, legal, and political troubles was unused; the main concerns among the thirty-six German states were their particular sovereignties. (Mann, p. 54)

The tripartite division of the old Empire--Austria, Prussia, and the Mittelstaten--remained essentially true for the Confederation also; the three suddeutschland states were distinct from the central states. Bavaria, Württemberg, and Baden, in the south, and the states in central Germany, were in turn distinct, by language, custom and frequently religion. From Saxony, Hanover, and the northern states. "Profound differences" existed within each grouping, differences which 
ranged from the arch-medieval, as was Mecklenburg, to Hamburg, which was economically very advantaged and itself desired closer trade and political ties with Britain. Austria, at least as early as 1815, began to make knife-sharp distinctions between itself and the "rest of the Germans", and Metternich consldered the Hapsburgs to be the predominant and most important political system. (Mann 1970, p. 55)

A barricade of tariffs and censorship of journals and periodicals separated Austria from her more "inferior"German neighbors. Frances I, Emperor of Austria, once remarked that he did not need scholars, but obedient subjects, making this statement to the faculty of Graz University. (Mann, p. 55) In fact, intellectual life waned, though music continued to thrive in the Danubian Empire; Austria nonetheless was fast becoming Europe's "China", i.e., isolated, retrospective, or at least the young democrat Ludwig Börne thought such was the case. (Mann, p. 56) The vacuum which Austria had created by its stubborn withdrawal and isolation from the rest of Europe was filled by prussia, the "mischief-maker", laughable; ignoble, Junker Prussia. Tallyrand tried to warn the Congress about Prussia, which, he asserted, was busy constructing a network of alliances with the nationalists, and was aspiring to conquer Germany for itself. (Mann, p. 56)

The Congress of Vienna's territorial divisions did nothing to lessen this Prussian threat to the peace of Germany, and in fact these divisions increased the potential danger. 
Prussia at last gained the Rhine, toward the west and south, and the river at that time became a curious source of a new wave of heathen "Teutomania" (Mann, p. 56); the tariff policies were directed toward the attainment of the economic domination of all of Germany. King Frederick William III was the enthusiastic supporter of Metternich and his son-inlaw, Tsar Nicholas. (Mann, p. 57)

The Rhenish provinces remalned restless; they had been promised representation in the new government, but this promise was not honored. The corporative representation, fashioned after medieval models, was weak and largely the excluslve property of aristocrats." ". - oppression took a more violent form, as well as being more futile." (Mann, p. 57) For the most part, the two powers of the German Confederation had their common ground in a negation which united them against western liberalism and southern constitutionalism alike. The stirring of the new Zeitgeist was determinedly resisted, and the suppression of young romantics, nothing if not passionate, became the Confederation's primary preoccupation. (Mann, p. 57) Metternich and Frederick WiIliam II refused to countenance any changes, and were most unsympathetic to the rising freedom songs which were sung by a great many young soldiers, returning from the wars of liberation and still hot with the ideas of liberte.

The new phenomenon, the Burchenschaften, or youth groups, which spread quickly from Jena to central and northern Germany, were nationalistic in scope, and were also Teutomanes 
who looked with suspicious German eyes on all foreign influence, especially despising the French. Even Heine, in his adolescence, was drawn to the fiery rhetoric of these groups, though his accident of a Jewish birth prevented any serfous belonging to them. In fact, these Burchenschaften lost no time in squaring themselves against the Jews, whose literary and frequently liberal-minded life made them conspicuous, and whose civil status was hotly disputed. The student groups held that constitutional systems were as distasteful as they were non-German. But at the same time, absolute monarchy was not viable to them either, and absolutist political literature, which included the Code Napoleon, was burned at the rally-festival at the Wartburg in 1817. Members of the Burchenschaften hated all things "modern", longed for a misty and ancient Teutonic past, and did their best to fashion themselves as genuine Teutons by their hair fashions and dark color of dress. (Mann, pp. 5758)

Karl Ludwig Sand, who assassinated Kotzebue, a minor dramatist who earned extra money by sending periodic reports to his master, the Tsar, gave Prince Metternich every reason for his anti-revolution campaign. Political persecution is one of the hallmarks of the 1820's, and the principles which lay behind it were the so-called "Karlsbad Decrees". (Mann, p. 59) A commission was established to investigate"subversive activities, "and the Burchenschaften were summarily dissolved. Universities were closely supervised lest any 
liberalism break out in them, and all university literature destined for publication was censored. (Mann, p. 59)

Thus the response of German princes, when In Europe and America there was nothing but talk of civil liberties and the sovereignty of individuals. The men of Berlin and Vienna saw revolution behind every tree and beneath every stone, and strove mightily against it.

In Teutschland und die Revolution, written in 1819,

Joseph Görres commented:

After four years of bitter party struggle, of senseless resistance against the demands of the times, of partial concessions by one side and exaggeration by the other, the situation has reached the point where the whole of Germany is in a state of spiritual ferment and its mood is such as usually precedes great historical catastrophes. The busiest intrigues and the cleverest demogoglc efforts from below could never alone have succeeded in arousing and embittering the quiet, peace-loving, sober and moderate German people to its very depths; that has been successfully accomplished by those at the top... (Görres, quoted in Mann, pp. 60-61)

Görres' Rheinfscher Merkux was banned in Prussia.

Charles $X$, the last Bourbon king, was expelled in July, 1830 , after he had moved to overthrow the constitution. Again, there was fighting on the barricades in Paris; the effects of the July Revolution were as dramatic throughout Europe as had been the days of 1789; other European leaders were once more frightened and worrled that the consequences of Charles' expulsion would spread and grow. And spread it did; in August, the revolution broke out in Brussels, and in Belgium, Belglans revolted against the bureaucracy of the king; in November, the 
Poles rose against Russian oppression, and in February,

Romans revolted against the pope. (Mann, p. 64) In 1831, the movement for parliamentary reform in England reached large and heated proportions.

In Belgium, an independent, neutral kingdom was created, and the constitution was the source of rule, not the king. (Mann, p. 64) Tsar Nicholas peopled the gallows with rebelling Poles; Prussia assisted the Tsar by mobilizing on Its eastern frontiers, with the aim of preventing any further spread of the revolt to Posen (Poznan), its Polish province. There was also considerable enthusiasm and excitement for the Polfsh upising throughout the Confederation; the tone of the radical groups in Germany in the $1830^{\prime}$ s was much more strident, not at all like the Burchenschaften of twelve or fourteen years previously. This tone was liberal, international, and, once more confirming Metternich's worst fears, the model and provacateur was France. "The speeches that were made at a political meeting in Hambach in the Palatinate in 1832 might just as well have been made by French or Italian leaders." (Mann, p. 64) But Heine was not so inclined, writing later:

- . Granted that at the Hambach French Liberalism preached 1ts wildest doctrines... on the Wartburg, on the contrary, there prevailed that narrow-minded Teutomania, which whined about charity and faith, but whose charity was nothing else but hatred of the stranger, and whose faith consisted only in irrationality, and which could find. . . no better employment than the burning of books... . 
Have these impenetrable fools, the so-called Germanists, entirely disappeared Erom the scene of action? No... Most of them... disguised in the colours and rhetoric of liberalism - - became all the more dangerous to the new Opposition, during the political fire-and-tury period which followed the three days of July (1830). Yes, the camp of the German men of revolution swarmed with these former Germanists, who with unwliling lips lisped out the modern password and actually sang the 'Marselllaise'. . . they made horrible grimaces over it.. (Heine, quoted in Legge 1970, pp. 109-110) (author's transiation)

By the $1830^{\prime} s$, most of the small states surrounding Prussia had been economically forced to join the Zollvereln; they joined one by one, owing mainly to Prussia's high transit duties. By the time Heine had fled to Paris, internal German customs barrlers had largely disappeared, the direction of trade policy being controlled by Prusia.

It is important to discuss briefly the impact of a new fact in Prussia, in all of Europe in the 1830's. The new railroads, forged by German workers from the iron of Alsace and the coal mines of silesia (now Prussia), interlaced and connected the political framework of the Zollverein. The first major line ran from Leipzig to Dresden. By 1845 , there were 1,250 miles of railway tracks in Germany; by 1855 , there were almost 5,000 miles of track. (Mann, p. 65) The railroads created a most profound change in Germany; theix construction produced, consumed and re-produced capital; mining operations boomed almost overnight, as did the lumber industries, and new machinery was designed. New kinds of workers were also created, among them industrial laborers, 
engineers, offlce workers. People were displaced at a rapid pace; they moved to the towns and became workers in the swelling populations of factory, foundery and office workers. News spread swiftly to all parts of this new, "modern" Zoliverein, wealth and poverty seemed to rise simultaneously overnight in the radically altered towns and cities--the poor were transformed into a new kind of laboring poor, into proletarians. (Mann, pp. 66-67)

There was Iiterally a new Germany by the beginning of the 1840's. The age of Teutonic knights, of mythical chivalry and ritual, was gone forever, except in numerous romantic writings. In Barmen, the boy Freidrich Engels walked by the smoke-belching factories on his way to school. He saw workers--workers which included among their ranks children his age and younger--"breathe in more coal smoke and dust than oxygen." (Mann, p. 67)

The above-cited excerpt of Heine's prose works is a good example of another modern phenomenon characteristic of Germany in the $1830^{\prime}$ s and early $1840^{\prime} \mathrm{s}$. Tendenzkunst, or Tendenzliteratur --"tendency" art or literature--was one of the forms which the new interest in realism assumed. The "tendency" Itself is generally seen to be the socjo-political bent or stance of the artist or writer. That "tendency" could exist either latently, or overtly and vigorously asserted. Poetry, that is to say some poets, assumed a personal and generally self-appointed stature as liberator or legislator, and became in themselves and in their writing the spokesmen of 
human travail. The art consciously--though not always artistically--emerged and functioned as a style of social and political consciousness and criticism, viz., Delacroix's paintings of the July Days of Paris and the Greek struggle, Byron's obsession with and cynicism about possible socialpolftical change, Heine's "letters" to and about Germany from Paris. "Tendency" was, nonetheless, a highly personal matter, the subjectivism varying considerably from artist to artist. (Baxandal1 and Morawski 1973, pp. 11-12)

Nor did Tendenzkunst or Tendenzkunstlers find a very receptive audience in the Germany of 1830 . In the thirtynine German-speaking principalities, readers were long accustomed to and content with a reflective, usually aesthetic discourse which was at bottom concerned chiefly with a glorification and sentimentalization of past achievements, and which likewise displayed a passionate fascination with all things medieval. (Sagarra and Tint 1971, pp.69-70) These readers, living in a Germany which prided itself, furthermore, on the high literacy of its subjects, were still very much satisfied with the idealism yet very fashionable in the 1830's, and even the Olympian Goethe was very likely more esteemed for his exceptional personality and reputation than for his work, which was poetry, and which Goethe himself considered to be death to the old ways of thinking, and in that a liberating force. Even so, the Goethe-cult had declined considexably before his death in 1832, and his dramas and poems were 
unread. (Arnold 1865, p. 108; Sagarra and Tint, p. 70)

The romantic poetry of Heine's contemporaries--Görres, Brentano, Arnim--was preferred by the reading public, and the old style was churned out in endless imitations, continuing until it died of sentimentalization, of exhaustion and other natural causes. (Arnold, p. 109) Helne followed Goethe, though Heine himself would have quibbled with that assertion; but it remains true that he did follow the revolutionary standard of the old olympian in that he placed the standard within each individual where most of his contemporaries placed it outside of the individual.

The immediate aim of all our most recent reforms or institutions is relatively the rehabilitation of matter, the restoration of it to its dignity, its moral recognition, its religious sanctification, its reconciliation with the spirit. Perusa will again be wedded to Prakriti. (Heine 1834-35, Leland, p. 93)

Heine's naturalism, which like Goethe's was a mortal wound to the old, backward thinking, transcended and transformed ordinaxy, acceptable romanticism. A self-proclaimed "Child of the French Revolution," Heine, like the Revolution itself, labored all his life to shatter the old and decayed, and applied the revolution's ideas to his 1 ife as well as to his poetry. In both instances, there existed no trace of feudalism; Heine was the first truly modern German poet, a curious admixture of French liberalism and socialism, Hellenism and "Nazarenism" 1, which he now despised, and now yearned toward; his poet's heart, he said, was split in two, as is the world.

1 Helne's word, not Arnold's; Heine meant by "Nazarinismus" the New Testament generaliy, and Christian dogma specificaliy. 
Though Matthew Arnold would crown him only with the laurel, Heine nevertheless also deserved the credit he so destred for his labors in Ereedom's battle. "Wherever a great soul speaks out its thoughts, is Golgotha." (Heine, quoted in Leland, p. 83)

As had been the case in the 1810's, the Radicals of the $1830^{\prime} \mathrm{s}$ were feared, and were taken seriously enough in Prussia that a new wave of political suppression and persecution welled up in reaction. Hundreds of malcontents were sentenced to death, though in most instances the sentences of execution were revoked, and the offenders were condemned to rot out their days in Prussian fortresses and stone prisons. (Mann 1970, p. 65) The Prussian officials prided themselves in that no one had ever died of starvation in their prisons. (Mann, p. 66) Many young people fled; there was a mass migration to Brussels, to London, to Paris, and to America. "The contrast between the existing political system and the intellectual resources of the country was great." (Mann, p. 65) - - in order for the folk tribunes to have any influence, our Teutomanes must now and then risk a word of freedom against the German rule, must imagine such a word in the impudent fear of their hearts; their rulers will gladly pardon an occasional, slight demagoguism if they the more incessantly preached hatred of the French. These rulers do not suspect that our princes no longer fear France, that they have no more need of national hatreds for their defence, that they consider the King of France a secure enough prop for their own monarchical principle. (Heine 1837, p. 66) (author's translation)

The Tendenzkunstlers were the true heirs of Goethe, were the prophets of the Zeitgeist, and knew themselves to be the 
children of the French Revolution. "Modern" literature, i.e., Iiterature that embodied in its prose and poems cultural and historical content and criticism--was recent and rare in the $1830^{\prime} \mathrm{s}$. Hegel, according to Heine, had sald: "If anyone had ever written down the dreams which men had dreamed during a certain period of time, one might gather from those dreams a very accurate picture of the spirit of that time." (Heine 1845, quoted in Leland, p. 436)

"Social novels", such as those of Mrs. Gaske1I, or Dickens, or Melvilie, or Balzac, or anything Iike Blake's "Songs of Innocence" and "Songs of Experience" were simply not to be found in the Germany of the thirty-nine states. (Sagarra and Tint 1971, p. 69) The growing interest in politics and public affairs, which began with the July Revolution ousting of the Bourbon king, and which only intensified during the Forties, did not spring from any renaissance of political liberty. (Sagarra and Tint, PP. 126-127) on the contrary, what it did reflect was an entirely new sentiment and feeling, as typified by Heine, that literature, in both its artistic and journalistic forms, was indeed an essential and vitally important component of political activity. Sagarra, p. 132)

- . in the little chronicles of hopes, needs, misfortunes, pains and joys, errors and disappointments, with which the individual man spends his life, in these human histories you find also the history of humanity. In Germany, the world-order of the historical school, and the poets of the Wolfgang Goethe art period are wholly attached to this particular view, but lately 
they nurse a sentimental indifference to all of the Fatherland's political affairs, explaining away all their mawkishness. To its satisfaction, the familiar rule in north Germany understands and particularly values this view, allowing proper men to travel, men who have developed calm, good-natured, fatal thoughts beneath the elegiac ruins of Italy, and who afterwards, in communion with established preachers of Christian submissiveness, douse the three-day freedom-fever of the people with their little chiliy journals. Nevercheless, whoever will not or cannot be aroused by the free strength of the spirit may creep along the ground; every reign but teaches the future. . (Hefne 1834, pp. 285-286) (author's translation)

In many cases, the "art" suffered a good deal; it became a pulpit from which to preach ideological and social theortes. (Butler 1968, p. 146) In eyery case, "tendency writing" was "rebel" art which concerned itself with alienation, as the above example illustrates, and alienation was explained in political and historical terms, though usually also in. highly emotional and personal language. (Baxandali and Morowsk1 1973, p. 34)

The Tendenzkunstlers Heine, Ruge, Börne, Bauer, Enge1s and Marx were "cultured men run wild". (Löwith 1967, p. 65) Frustrated, deprived of or denied lecterns and open publication, perpetually anxious of arrest and falling finances, they squeezed their artistic and scholarly talents into pamphlets and journals; it was these men who were also among the first to have to depend solely upon their writing as livelihood, however meagre that may have been, and with their work the occupation of journalism came into existence in Germany. 
France is like a garden whence all the fairest Elowers have been plucked to form a bouquet, and that bouquet is called Paris. It is tre that its perfume has not now such power as it possessed after those days of July when the nations were overcome by it, yet it is ever beautiful enough to show magnificently on the bosom of Europe. (Heine, quoted in Leland, p. 94)

Paris, then, for the 33-year old poet ras a veritable rebirth; Heine was exhilarated in those first years. During the $1840^{\prime}$ s, Paris nourfshed and enthusiastically responded to the intellectual migrations from Germany, Poland, Italy, Russia, Hungary. Poets, painters, socialists, musicians, thinkers arrived almost daily and formed an agitared and often quarrelsome community of exiles and salon attendants. Heine, Turgenev, Liszt, Bakunin, Chopin, Delacrofx are but a few of the new artists of "realism" who were to be regularly found in the almost legendary salons of Countess d'Agoult and Princess Belgiojoso. (Schwarzchild 1947, p. 90)

Coming as he had from old-fashioned, provincial Germany, everything interested Heine; he visited all the sitesthe boulevards, museums, galleries--viewed paintings, heard the exquisite art of the virtuosi Liszt and Chopin, Iistened intently to all he heard. He wrote copiously, on all subjects, in a fever of enthusiasm. "I . . - am essentially an enthusiast," he wrote on the subject of himself and Goethe, "that is, I am so inspired by the ideal as to be ready to offer myself up for it." (Browne 1927, p. 125)

Depicted is a group of people during the July Days,. and in the center towers an allegorical figure, a young woman with a red phyrigian cap on her head, a. 
musket in one hand, and in the other the tri-colored banner.

- - In none of the many galleries of paintings is there such striking color as in Delacroix' July

Revolution. In this, the absence of varnish and shine, the smoking powder, and the dust which covers the figures like a grey cobweb, sun-parched shades almost thirsting for a drop of water--all these give the picture a truth, a naturalness, and one has from it a true feeling for the real face of the July days. - Holy July Days of Paris! You give eternal testimony to the primal nobility of mankind, which can never be wholly destroyed. You who experienced them are miserable no longer in the old graves; you belleve in the dignity of the people. Holy July Days! how beautiful the sun, and how great the people of paris: (Heine 1831, pp. 298-299) (author's translation)

The last ruler of the Napoleonic era died in 1840 .

Frederick William III was succeded as the ruler of fifteen million Prussians by his eldest son, Frederick William IV. The new king proved to be a supersitious, arrogant ruler, despite a more promising beginning; his absolute rule came from medieval days, and his equally medlevalist romantic Ideas were hopelessly at odds with the time; he was adamantly opposed to the liberals. "The contemptible Jewish clique strikes daily by word and example at the root of the German character," he wrote in a letter in 1845; "it does not (unlike myself) want to distinguish between the estates which alone can form a German nation; it wants to throw all the estates together:" (Mann, p. 69)

What a spectacle: That in the endlessly continuing division of society into manffold, various races, which oppose each. other with their petty antipathies, bad conscience and brutal mediocrity, and which, because of their reciprocal ambiguities and suspicious position are all, without exception, ruled and treated by their masters as merely licensed existences! (Marx 1843, p. 491; Tucker, p. 14) (author's translation) 
Heine and Börne were isolated, self-contained characters even before the July Revolution, yet they arrived first at the significance. of it, and upon them a new generation is founded. (Engels, quoted in victor 1970, p. 24) (author's translation)

It is most significant that Heinrich Heine became an interpretor of French political and social activities to the Germans, that he and Ludwig Börne offered the spectacle of themselves to the world, as bitter antagonists both to the German rule and finally to each other; that they personified, in a completely self-conscious and vociferous manner, the dishonor of exiles. In their struggle for personal, artistic, and intellectual freedom, which Engels correctly noted had gone on for years, was concealed the answer to the problems and difficulties which pursued all the progressive, liberal minds of the time. (Victor, p. 24) The fundamental questions of liberty and freedom which arose in this most visible, imprudent and public strife of Heine's personal life may serve to explain Karl Marx's acquaintance with Heine generally, and his work with the poet specifically. (Victor, p. 24)

In a letter to Heinrich Laube, Heine wrote in November, $1842:$

It is the cowardly lie of Gutzkow and his consorts - . that my political convictions are suspect, I! the $I$ who is perhaps the most resolute of all revolutionaries, the $I$ who has given no ground to the Fatfingers of the ranks of progress, the $I$ who have brought such great offerings to a great cause--I have almed at apostacy, for the sake of the unfatchful, for the benefit of the servile. 
What is given at the first, when I am in direct opposition to (gegen) the hypocrite-heroes and mouthpatriots, and tread upon the former saviors of the Fatherland? . .

We need not play to the Prussian doctrinaires, we must harmonize with the 'Hallischen Jahrbüchern' and with the 'Rheinischen Zextung', we must not conceal our political sympathles and our social antipathies: we must call the bad by its right names and defend the good without regard for the opinion of the world. (Heine, quoted in victor, p. 27) (author's translation)

This letter reveals two important things: It is well to keep in mind the constant bickering and sniping of the German exiles in Paris. All, like most ideologues, were absolutely convinced of the righteousness of theit bellefs, and the good of their cause, but very seldom were any of them in agreement as to purpose, procedure, and frequently. ideology. Some bellowed for an armed invasion of the Fatherland, an idea Marx found as laughable as it was dangerous; very few agreed upon how to further their mutual cause and their common batte for the liberty and inteliectual freedom of the German Volk, who were long accustomed to the habit of allowing princes to do their political thinking for them. Heine is still famous for his acidic attacks, and for his devastating wit, 1 and 1 t is in keeping with his almost religious devotion to the ideal of freedom that he pleads for honesty among the exiles about their various disputes and differences, that he does not make any atrempt to gloss over their many and frequent contests. He seriously quarreled with

IEven Freud has dealt with the powerful hostility in Heine's wit. So did George Eliot: "German Wit", 1884 ; Freud's "Witz und Seines Beziehung zum Unbewusstein." 
Börne, the Jewish democrat, and wrote some regrettable, vicious things in the biography of his former friend and comrade. 1

The life of exiles in the late $1830^{\prime} \mathrm{s}$ and throughout the $1840^{\prime} \mathrm{s}$ was unpleasant and difficult to the point that the exiles accomplished more for the censor's cause than they did for thelr own. In 1836, the Prussian and Federation Ban came, a political muzzle which included all the works of Heine, and which lasted until 1842, though it remalned operative well into the decade. Open conflict was in fact the normal rather than the abnormal condition of the relationships between exiles. Ruge, for example, in a pique in 1844 regarding the failing state of the "DeutschFranzösischen Jahrbüchern," fastened the entire blame upon Marx, calling him an "impudent Jew". (Sprigge 1949, p. 46) Heine mused at the same time that the national disease of the Germans, which included Teutomania, was insanity, expecially when Germans resided in France. There, he claimed, for some mysterious reason, this natural tendency flourished and grew to "monstrous proportions on the Paris boulevards." (Sprigge, p. 47)

"Yes, poverty," Heine wrote in 1842, "Is the sad lot of the greatest philanthropists, of the thinkers who live in Erance." (Heine, quoted in Leland, p. 461)

The second important feature of the Heine letter cited above is that it demonstrates the fact that Heine, in Paris 1 Ludwig Börne, 1840 . 
since 1831, was well-acquainted with the writing and opinLons of the young Karl Marx before Marx ever thought of golng to France. The "Hallischen Jahrbüchern" were begun in 1838 by Ruge, were contributed to by Maxx, and had quickly become the "gathering place for all the restless spirits" of Hegel's succession. (Mehring, quoted in Victor 1970, p. 28) The "Rheinischen Zeitung" was likewise a polemicalpolitical journal, edited in Cologne by the young Karl Marx, from October 1842 until March 1843, when it was effectively gagged by the censor.

At Ruge's urging and assurances of income and housing in Paris, Marx arrived In that city with his already pregnant bride, in late October, 1843. Immediately he resumed his studies and his criticism of economics and history; he embarked upon an in-depth study of French socialism. But chiefly, and most importantly for Marx, he continued in his labor against the regime in Germany with admirable strength and vigor. (Victor, p. 36) He worked patiently and tirelessly with Ruge and the "Deutsch-Französischen Jahrbüchern" and with other members of the German Emigration (political exiles).

Their reading public in Paris consisted of 85,000 Germans, workers and exiles and tourists, as well as the secret admirers of their illegal and contraband material still in Germany. (Sprigge, p. 44) Standing in the midst of this fluryy of activity was the restless, anxious coeditor of the scholarly-political journal, Harry Heine, 
who gladly accepted his own part in the Bundes des Gerechten (League of the Just, or Covenant of Righteousness). (Mende 1970, p. 212) Heine and Marx Immediately became Eriendly, and Marx spent the following thitteen years defending Heine against friends and foes allke; Heine for his part took the youngar and more Improw Lonabla Marx around to the salona and circles, Introducing him to the Iuminaries of Parisian intellectual Iife. It was through Heine that Marx became acquainted with and attracted to Proudhon, the brilliant French socialist, and Marx spent many evenings in company with the Frenchman from Besançon who had boldly proclaimed that "property is theft", teaching him German Ianguage and Ideas. (Sprigge, p. 48) It was also through Heine and in the Paris cafe society that he became familiar with Russian exiles, among whom he felt comfortable, and whose center of gravity was Count Grigori Tolstoi. (Schwarzchild 1947, p.90) It was here, and again through Heine, that he met the idealist Michael Bakunin. (Schwarzchild, p. 91) Heine exclaimed that Marx was the most sane, resolute and intelligent of the exiles of Paris in 1844. (Sprigge, p. 47)

In August of that same year, Marx and Heine began their co-authorship on the journal "Vorwärs". In September, Heine wrote to Marx that he was preparing, though"alarmed by a signal from Above for his departure," (Victor 1970, p. 35) for extensive participation on the journal, as was expected of him by the other exiles. The alarm about the "signaI" might mean 
two things: that he was already informed of the forthcoming expulsion, or that he had premonitions about his health, which was failing. To that end, he requested that Marx review and criticize his newest poem, which, if found suitable, could become a contribution to the journal. The poem was Deutschland: Ein Wintermärchen (Mende, p. 217); it was, Heine claimed, the "free-est song he had yet written". (Victor, p. 45) He had nefther forgotten die blaue Blume ${ }^{1}$ of romanticist dreams, nor altogether forsaken those of communism. (Victor, p. 45)

Ein neues lied, ein besseres lied

o Freunde, will ich euch dichten:

Wir wollen hier auf Erden schon

Das Himmelreich errichten.

Wir wollen auf Erden glüchlich sein

Und wollen nicht mehr darben;

Verschlemmen soll nicht der faule Bauch

Was Fleissige Hände erwarben.

Es wächst hienieden Brot genug

Für allen Menschenkinder,

Auch Rosen und Myrten, Schönheit und Lust

Und Zuckererbsen nicht minder.

$\mathrm{Ja}$, Zuckererbsen für jedermann,

Sobald die Schoren platzen!

Den Himmel überlassen wir

Den Engeln und den Spatzen. (author's translation, Appendix A)

"The poem, one of the most brilliant and characteristic products of Heine's pen, is an index for the Germans of what severed them from this Jew. The Aryan nations have their Tersites and their Loki, but such a character as Ham, who.

1 die blaue Blume: the blue flower, object of the Romantic search, which, if found, like the Holy Grail, would change the course of life. On Earth. 
uncovers his father's nakedness, is known only to Jewish saga." (Treitschke 1919, p. 135)

In November of 1844 , Heine reviewed Marx's work on the essay "Zur Judenfrage", and offered critical and literary suggestions to Marx. (Mende, p. 219) There is also some evidence to support the possibility that the two men also collaborated on Marx's "Economic and Philosophical Manuscripts" of 1844. (Mende, p. 220) They also worked together on seven of the Zeitgedichte (Timepoems) that Heine published first in "Vorwärts". (Sammons 1969, p. 210)

Ich will mein volles Fretheitsrecht: Find' Ich die g'ringste Beschränknis, Verwandelt sich mir das Paradies

In Hölle und Gefängis. (Heine, quoted in Sammons, p. 212) (author's translation, Appendix B)

The Prussian Minister of the Interiox of course was not blind nor deaf to the activities of the emigrees-his police, their queues hanging beneath theix noses, as Heine put it in. Deutschland: Ein Wintermärchen, had impounded all their.1iterature at the frontier crossing at the time they had left the German border. (Mende, p. 212) Nor was the Paris government entirely unconcerned with the Germans' activities in the fair city; with an eye to the part the German Intellectuals and radicals might be playing in the advance of yet another revoIution, the government of Louis Philippe, "the representative of money", ${ }^{1}$ submitted to Prussian pressure, and agreed, late in 1844, to curtail German radical journalism tn France. 1Eutetia, p. 464 , Vol. 16 (Heine). 
(Sprigge 1949, pp. 52-53) "The society of our time defends itself out of flat necessity without belleving in its rights." (Heine, quoted in Leland, p. 464)

The suppression of "Vorwärs" probably resulted in making it more famous and controversial--also more heroic-than if the French and Prussian officials had simply ignored 1t. Succumbing to Prussian pressures, the French envoy in Berlin in 1843, following Guizot's instructions, enquired what the French government should do with Heine, in the event that he had become a naturalized Frenchman. The Prussian authorities responded that they realiy had no records of Heine's official nationality, but that they would treat Heine, should he return to Germany, with all the courtesy accorded a citizen of France traveling in their land. This they did. when Heine returned in 1844 for a visit to family and friends in Hamburg. (Treitschke 1919, p. 596)

Apparently, Heine had applied for naturalization and received 1t. In any event, the French government was satisfied that Heine was officially and legally French, for when the order of expulsion of the German radicals came in January of 184.5, Helne was the only exemption. (Treitschke, p. 597-98) The poet's modest pension from Louis Philippe, a topic of much consternation among the more idealistic and puritanical exiles, was in all probability granted to a citizen of France. Marx, Engels, and the rest of the mostly Jewish, pugnacious, radical irritants, socialists and communsts, 
immediately prepared to depart Parls; Marx went to Brussels,

having heard that it was the most open and receptive city

on the continent of Europe.

Life is neither means nor ends. Life is a right. Life wants to make this right count against perrifying death, against the past, and the way to make it count is revolution. The elegaic indifference of historians and poets, should nat cripple our energy in this matrer, and the fanaticism of the benefactors of the future should not lead us astray so that we risk the interests of the present and the rights of man which first have to be fought for-the right to live-- "Le pain est le droit du peuple," Saint-Just said, and these are the greatest words spoken in the entire Revolution. (Heine, p. 287) (author's translation)

Marx conveys much the same conviction in the "Economic and Philosophical Manuscripts of 1844," but without the 1yricism of his friend:

We see here how the passage of naturalism or humanism distinguish themselves from the ideal as the material and at the same time that both are unified truth. We see also how only naturalism is capable of grasping the act of Horld history.

Man is a directly natural being. As natural being and as a living natural being he is endowed partly with natural powers, with iffe powers, an active, effective natural being; these powers exist in him as tendencles and abilities, as impetus or instinct (motive power); in part is he as a naturaliy bodily, sensual, objective being a suffering, a conditioned and limited being, which the animal and plant is also, i.e., the objects of his impetus exist outside him, as objects independent of him, but these objects are objects of his need, and toward participation and confirmation of his powers of being, indispensable; essential objects. (Marx 1844,. p. 650; Tucker, p. 93) (author's translation)

An attempt to make Heine and Marx Into identical personalities or ldeologues is foolhardy. Though they shared similar 
backgrounds, as Germans, as Intellectuals, as Rhenish Jews, as polftical critics and cxlles; though they shared the endless, taxing work against the stubborn Prussian government, they nonetheless occupied radically different positions as individuals. Their practices as historians, socialists and literati were not at all the same, as the textual examples plainly show. But their reciprocal, mutual influence is not limited to their differences as men, and may instead be rooted in those differences.

No two people could be visibly more of a contrast. Physically, Marx was referred to, affectionately and by Eamily and friends, as "the Moor"; he was dark, rather short, thickset and powerfully built. Heine, on the other hand, was slight, nervous, ill, 20 years older. However, both men shared a passionate preoccupation with the problem of a "world of abstraction without praxis", and they shared a vision of how this historical-philosophical-practical phenomenon functioned in Germany. (Mayer 1973, pp. 2-18)

But Heine was, in addition to being a poet, philosophically a democrat who could not abide the boistrous German workers' meetings; their smoky, beery gatherings aggravated , his migraine affliction, and stung his eyes. He was liber-: ally-minded, ibut could not or would not become a "good citizen". That would have been to admit defeat to the philistine world of bourgeols close-mindedness which he had spent a Iife satirizing, shocking, opposing. 
Es roch nach Blut, Tabak und Schnaps

Und nach gehenkten Schurten--

Wer ubelriechend im Leben war,

Wie musst' er in Tode duften!

(Heine, quoted in Sammons, p. 298)

(author's translation, Appendix C)

Heine had "surrendered to all the orgies of the intellect". (Thomas 1974, p. 86) His exile, his bread soaked in tears, he told Laube, was the price of his thought. A Tendenzkunstler, an intellectual, whose insights underlined his personal alienation, whose criticisms and attacks so stung his adversaries and friends alike, Heine was nonetheless among the vanguard of "modern" polltical-social thought. He was, Matthew Arnold insisted in 1865, the only poet to succeed in breaking the old chains of custom, successful even where Byron had failed, himself an undisputed master of disrespect. Heine greatly admired Byron, and emulated him even in dress.. (Arnold, pp. 121-122) "Not only was he (Heine) not. . 'respectable people', he was profoundly disrespectful.". (Arnold, p. 126).

It must be said that he was "profoundly disrespecteul" of Gentile and Jew equally. Jews, especially Rhenish Jews who hoped and labored for emancipation, as Gabriel Riesser of Hamburg, were furious and insulted; Riesser himself was aroused to such anger that he wanted to challenge the apostate to a duel. (Sammons, p. 451) During the Denkmalstreit period in Mainz (Monument-quarrel, 1897) newspapers gleefully reported that Reform and orthodox together signed a protest against the proposed monument. "What is the use of the ralmud now?" 
(Heine, quoted in Leland, p. 120)

Despite the efforts of protesting Jews, Heine has usualiy been classified as a "Jewish" poet, though his German was that of Martin Luther, and he thought, wrote, and spoke countless times of his homesickness for Germany. "Heine ist eben durch und durch Jude, kein echter Deutscher!", wrote Franz Sandvoss in an anti-Semitic pamphlet in 1896. (Sammons, p. 453)

- . Since you can be politically emancipated, without yourselves fully and without contradiction (widerspruchlos) separating from Judaism, therefore political emancipation is itself not human emancipation. If you Jews want to be politically emancipated, without yourselves being humanly emancipated, then che half-measure and the contradiction lie not only in yourselves, they lie in the essence (Wesen) and the category of political emancipation. If you labor under the misapprehension (or prejudice: Wenn ihr in dieser Kategorie befangen seid) of this category, then you share in the universal prejudice (allgemeine Befangenheit). (Marx 1843, p. 469; Tucker, p. 38) (author's translation)

Efforts have been made either to fit Heine into the overall contribution of Jews to German culture generally, or to dispense with him altogether, by Gentile Germans and JewishGerman nationalists alike. Gentile German liberals of good will at the turn of the century expected that Jews would not integrate in the nation as jews, but that in the process of. assimilation they would cease to be Jews altogether. The assimilation-minded Jews ascribed unqualifiedly to this view and were baptised into Christianity. But Heine, stubborn and elusive even in death, refused to rest in any one category, poetic, political or religious; he remained an embarrassment to all. 
Interpretarions of the poet's work vary with the prevalifng inteliectual winds--whatever the interpretors claim, Heine was and ts, like Isalah, a "disturber of the incellectual peace". (Veblen, quoted in Sammons, p. 459) The more fair statement to be made about Heine, indeed the most complece one, is this: Heine's persona is to be found in a wide Western spectrum wich includes the Vulgate, popular legend and ballads, German philosophy, Classical antiquity, two or three generations of literary tradition and convention, including the romantic, and Jevish tradition and lore also, which has been woven into the Western for 2000 years. 


\section{PART V}

\section{MARX}

Marx, the loyal husband and loving father, well understood that Heine was a complex, sometimes confused and frequently confusing soul, but his affection for the older poet was not diminished for that--in fact, Heine was the only person Marx was sorry to leave when he was expelied from Paris in 1845. (McCle11an 1970, p. 189) Marx clearly saw in Heine's destroyed life the literal and symboitc war, with its many defeats and too few victories, for human freedom. This understanding certainly accounts for Marx's apparent silence on the subjects of Heine's religious backsliding and alleged polftical heresies. To attempt to make these two men similar, or to force them into one philosophical mold, is not to recognize then by their own lights and on their own terms. It is more to the point to see in their thirteen-year long Eriendship the respect each had for the other, for their respective work, which, all said, was truly thetr common ground.

I now have Heine's volumes at home. Among other things that he related, when I went to console him, he detailed the lie which appeared in the Augsburger "Allegemeinen Zeitung," on account of the conditions of the receipt of Louis-Philippe's money, for which he was "attacked". The good Heine forgets intentionally that my intervention for him occurred at the end of 1843, and he also knew, though his facts are not hanging togiether now, that this came to ilght after the February Revolucion of 1848. But let it pass. In the fear of his 11 lness and bad conscience, and the 
old dog has a monstrous memory for all such filth, he needs cajoling. (Marx, quoted in Victor 1970, p. 86) (author's translation)

On this common ground, the very different characters of Heine and Marx found free and open exchange; many ideas were traded back and forth during many evenings' debates, Marx Incessantly smoking his pipe. Heine and'Marx equally contributed to the fournals, "Rheinischen Zeitung," "Neues Rheinischen Zejtung", and "Vorwärts".

- . the masses will no longer suffer their earthly misery and thirst for happiness with Christian patience. Communism is a natural result of this altered world view (WeIfanschaung), and it spreads over all of Germany. It Is guite as natural an appearance that the proletariat in its battle against the progressive spirit, possess as Fihrer the philosophy of the great school; this goes from the doctrine to the deed, the final aim of all thoughts, and formulates a program. How does it run? I dreamed of it long ago and declared in these words: 'We will be no sansculottes, no frugal. bürgers, no well-polished presidents; we will establish a Democracy as magnificent, as holy, as inspired as the gods. Your (the Germans) longed for, single aspiration, abstinent habits and unseasoned delights; we, on the contrary, desire nectar and ambrosia, purple mantles, costly perfumes, voluptuousness and splendor, smiling nymph-dances, music and comedy... (Heine, 1845-46, Victor, p. 84) (author's translation)

It is equally useless to speak of Heine as a pre-Marxist -he was, if nothing else, an artist and internationalist freethinker, a poet of powerful vision. Socialism, the "religion" of Fourier and Saint-Simon, was not a passing fascination for him; rather, it was a vital, modern concept of a society that would pass beyond that of a stifling bourgeols life. In his "conversion" to Saint-simoniantsm he had forged an unwavering conviction that had at its center the union of Ereedom 
and beauty. (Mayer 1973, p. 13)

The very man who had, In 1844, argued with the young Marx about French socialism and communism, comparing its adherents now to the early Christian cells, now to the gods, was, by 1854, anxious that communism was, or rather that the Communists were, espousing yet another religious de riguer, which, in its rigid orthodoxy, despised art and philosophy. - - In the great and glorious Book of Daniel lies the legend which I commend, not only to the excellent Ruge, but also to my still more deeply deluded friends. Marx, yea even unto Messleurs Feuerbach, Daumer, Bruno Bauer, Hengstenberg, and whatever else they nay be called, these godless self-gods-for their edifying consideration. But there are also in the Bible many beautiful and remarkable narratives well worth their attention, as for instance in the very beginning, that of the forbidden tree in Paradise and the serpent, that little private professor who, six thousand years before Hegel was born, taught the whole Hegelian philosophy. This bluestocking without feet showed very shrewdly how the Absolute consisted of an identity of being and knowing (Sein und Wissen)how man became God through knowledge, or, which is the same thing, how God in man first attained to knowledge of Himself - - Truly this Biblical tale, and with it the speech of the serpent, are ever in my mind, and $I$ would fain place it as a motto to this book, just as one often sees before princely gardens a board with the warning: 'Here are set man-traps and spring-guns.' (Heine, quoted in Leland, pp. xlii-xilit, 1852)

The English Chartists were driven by hunger, and not by an 1dea; as soon as they had stilled their hunger with roast beef and plum pudding, and their thirst with good ale, they were no longer dangerous; satisfied, they fell like leeches to the earth. The more or less hidden leaders (Führers) of the German Communists are great logicians (Logikex), of which the strongest have emerged from the Hegelian School, and they are without a doubt the most talented heads, and the most energetic characters of Germany. These Doctors of Revolution and their sympathetic, determined disciples are the first 
men in Germany; they live life, and the future belongs to them.1 (Heine, quoted in Victor 1970, pp. 85-86) (author's transiation)

Heine had flirted with communism, and the Communists certainly flirted with him. He had also asserted that the coming world war would be waged not between rival nations or religions, but between the haves and the have-nots. (Sprigge 1949, p. 47) In 1842, Marx himself had not yet left the Young Hegelian socialist ideas behind him, and he doubted that communism would ever amount to more than a theory. (Sprigge, p. 47)

But in 1854, following the stroke in 1848 that slowly killed Heine for eight years, not even the young doctor from Trier could banish Heine's fears of yet another philistine asceticism, another crucifixion of the flesh and senses, nor could Marx rout Heine's suspicions that Kant and Robesplerre would be the final victors in their harsh and bloody revolution. (Mayer, pp. 13-14)

The entire historical view hitherto existing has either wholly, calmly disregarded this true basis of history, or has assumed it to be only a matter of secondary importance, which, in the historical development, stands outside the chief context. (ausser allem Zusammenhang steht) History must thereby always be written according to a standard lying outside itself; the true production of life appears as un-historical (ungeschichtlich), while the historical, as separation from ordinary life, appears to be extra-terrestrial (Extra-Uberweltlich). The relationship of humanity to nature is herewith

$I_{\text {An }}$ interesting variant, which appeared in 15 September 1854 in "Revue des deux mondes" reads, in the last sentence: ". . und ihnen, furchte ich, gehört die Zukunft"--to them, I fear, belongs the future." 
excluded from history, by which means the opposition (Gegensatz) of nature and history is begotten (erzeugt wird). - . The 'imagination' (Einbildung). the 'concepcion' (Vorstellung) of these have come to determine men beyond (or above: über) their true practice (Praxis), and have been transformed into the sole decisive and active force (Macht) which determines and governs the practice of these men (die Praxis dieser Menschen beherrscht und bestimmt). (Marx 1846, p. 48; Tucker p. 129) (author's translation)

Marx halled the necessity for a new man, for communistle man, based on Hegel's Aristotleian prototype, the polis, wherein man is a political, social being "whose freedom is a personal integricy based on relationships with others." (Löwith, P. 156) Polls becomes a particular concept of work- i.e., thought and action; it has become the modern vita activa, which is the natural state of free man. (Arendt 1958, p. 73) Iife, for the free man, is one of action and speech, is a life related to a world of things and other men. What is in fact "unnatural" is the privation of private property, which in itself is the expropriation of free individuals, the monopolization of "labor-power", which moves always in the same circle. The reproduction of life is twofold, 1.e., it is that of biological life and "Iabor-power". Man's existence is in reality a process of realization (actualization) of his freedom. Reason pre-supposes, in the concept of polis, the power to act, indeed the right to act, and is in itself the reality of the truth which is freedom (die Freiheit), which is the work of the mind and the hands. Reason is culminated in freedom. "Freedom is the innermost dynamic of existence". (Marcuse 1960, p. Ix) 
Since the fully formed proletariat represents; practically speaking, the completed abstraction from everything human, even from the appearance of being human; since all the living conditions of contemporary society have reached the acme of inhumanity in the living conditions of the proletariat; since in the proletariat man has lost himself, although at the same time he has both acquired a theoretical consciousness of this loss and has been directly forced into indignation against this inhumanity by virtue of an inexorable, utterly unembellishable, absolutely imperious need (die Not) that practical expression of necessity (den praktischen Ausiruck dex Notwendigkeit)--because of all this the proletariat itself can and must liberate itself. (Marx, pp. 704-705; Tucker, p. 105)

(author's translation)

As in Hegel--"all the phenomena of the age" reveal that all satisfaction in the old way is herein ended, that in order to "abolish what is negative in the existing world, in order to find one's place within it, in order to live," (Löwith, p. 162) a way must be found from "idea" to "Iife", to reality from reason. Marx's "better man" (the man of Heine's

"besseres Lied") sees all the contradictions of a materialistoriented life and disdains the restrictions of his alienated life-powers which permit only the contents of his imagination to be his "true nature"--such is the nature of Goethe's cold marble statues beneath the elegiac ruins, and also the fate of Shelley's Alastor, and the fate of Hölderlin's Hyperion. The fully-human nature of this new man despises the slavery of his labor, the endless labyrinth of the production of material life which would be, should be, freely his, but is not. "The age is moving irresistably toward the actions of great individuals, toward the movements of entire peoples, 
toward the way poets have represented nature and destiny. (Through metaphysics), the restrictions are given their boundaries and their necessity in the context of the whole." (Hegel, quoted in Löwith, p. 193)

The materialization of these great ideas depends upon the living activity of men. It depends upon the workmanship of free individuals for fulfillment; human life is rightfully. engaged in the process of world-building. Comprehension in Marx (die Vernunft), as in Hegel, means not simply an intellectual understanding (der Verstand), but an active criticism and transformation of "what is" Into "what must be", "what will be".

Iike his philosophical forbears Goethe and Hegel, Marx understood that Gestalt comprised living within the totality of all that has being, and that by "not transcending himself, he could achieve the insight that the entire circle of apprehension is included in the unification of 'must' and "will'." (Goethe, quoted in Löw1th, pp. 195-196) The body "must", the spirit "wil1".

Indeed the animal also produces. It builds itself a nest, dwelling, as the bee, beaver, ants, etc. Only it produces what it alone needs (bedarf) for itself or its young; it produces one-sidedly, while man produces universally; it produces only under the command of immediare physical needs (Bedürfnisses), while man, himself free (der Mensch selbst frei) from physical needs does produce, and first of all produces in the Freedom (in der Freiheit) from same; the animal produces only itself, while man reproduces the whole of nature; the animal's product belongs immediately to its physical body, while man, free, (frei) converts the (gegenübertritt) product. 
- Even in the cultivation of the objective world, man therein demonstrates himself as genuinely a species-being (Gattungswesen).1 This production is his active species-being. Through it, nature appears as his labor and his reality. The object of labor is therefore the condition (or realization, Vergegenständichung) of the species-being of humanity . . (Marx 1962, pp. 567-568; Tucker, p. 62)

(author's translation)

Marx forges Vico's three ages (Gods, Heroes, Men) together Into one, free humanity.

You demand that one should begin with true germs of life, but you (che Germans) forget that the true seeds have thus far only sprouted in the brains of the German people. (deutschen Volkes) In a word: You cannot abolish philosophy without realizing it. (Marx, p.495; Tucker, p. 14) (author's translation)

When a man's life has become merely a means of livelihood, his life is not freely his; his labor is not his own. If his labor prevents only certain animal privations, i.e., loss of food, shelter, clothing, he is a priori unfree. His freedom is in this way subverted, becomes economic and political, which is not the essence of that freedom. Labor that is performed is done so only to prevent animal privations, and men are like the animals in their bodily necessities, et, al, but men are nonetheless not animals or beasts of burden. The poorer a man becomes, the more he must labor, for wages in a capitalistic economy, In order to fulfill the most basic needs. And his slavery to wage-labor dehumanizes him, taking from him what is by nature his own, that is to say, his polis, his Ereedom.

${ }^{1}$ Gattungswesen may also be here interpreted "husbandman", the word In Getian for "husband" being Gatte. Certalniy Marx In this passage is describing a netaphotical husbandry, viz., the "cultivation" (Bearbeiten) theme, of the natural or objective wox 1 d. 
This is the condition of the alienated human world in Marx's thought; and it is an historical condition also.

Indeed, Marx distinguishes between "true" freedom and "false" freedom, the latter being mainly that which is mater1al, wherein reforms of distribution would not reform the basic relationship of man to his world or man to man. Proudhon's socialism failed, in Marx's view, to change the Eundaments of the problem, which is that "property is theft"; private property and capital are identical, claims Marx, and the values in Proudhon's thinking are still attached to things, not to man. So long as this is the case, capital continues to reign.

"True" freedom, or the condition of communis, is a process which alters the political, moral, and legal behavior of a society, because it (would) alters equally the contents and forms of politics, law, and morals; by such a process is the economic and material behavior of a society transformed. This world truly, freely, belongs to communistic man; he built it, re-creates it as and by means of his Gattungswesen, gave. it various names; man does not passively, unfreely, belong to a hostile alienated world. Full human freedom is composed by the work of. man--the work of his ideas, his speech, his arts, as well as of his hands; labor, as man must also eat, have shelter, etc., is necessary; men are compelled to labor In order to eat. But art, IIterature, history, philosophy, et. al., arealso free, and comprise the world of man. This 
is also the created world of man, and it freely belongs to

its creator. In this realm of freedom man is productive of his own volition, not out of compulsion for wages or animal survival. "Really free labour, the composing of music for example, is at the same time damned serious and demands the greatest effort." (Maxx 1971, p. 124) The free production of these human creations are the very things which distinguish man's activity, his labor, from that of the animals.

But eating and drinking belong to life before all else. Shelter, clothing and other things. The first historical act is therefore the begetting (die Erzeugung) of the means to the satisfaction of these needs (Bedurfnisse), the production of material life itself, and in fact is this an historical act, the fundamental condition of all history, which even today, as for a thousand years, must be hourly and datly fulEilled in order that mankind might only maintain life. (Marx 1846, pp. 28-29; Tucker, p. 20) (author's translation)

- . the division (Teilung) of labor (Arbeit) offers. us directly the firstexample, in that, so long as men find themselves (befinden) in natural society, so long also as the division (Spaltung) exists between the particular and the common interest, so long as activity also is not freely (or willingly: fretwillig), naturally, divided, the original act of man is alienated (fremden). from him at the beginning, becoming an opposing powex (gegenuberstehenden Macht wird), which subjugates (unterjocht) him and imposes mastery over him (ste beherrscht). (Marx 1846, P. 35; Tucker, p. 124) (author's translation)

Marx argues for the actual, the "realization" of a manmade world, which is natural, and natural to man. Such a world is made of "natural" materials, but is not a creation of nature's at all. Work (Werken) and free labor (Arbeit) are, equaliy, the twin aspects of this "naturalism-humanism-communism", which is, primordially, the adamic activity and is the world of man. 
Again: In addition to laboring for life's reproduction (Necessity)--which is common to all and is not at all rightfully or natural1y "private property"--rhere is the labor of philosophy, fishing, muslc and the cultivation of roses. These are, directly, work, man's self-creation, objective and compelling. "Work is a positive, creative activity." (Marx 1971, p. I26)

There are two parallel worlds; that of nature and that of man, both of which are "natural" creations. But man's world is created out of nature, nature being transformed, not transcended, by man's work; nature recreates only itself in its constant, cyclical process, which is also the condition of alfenated labor. Nature itself is mindless, or unconscious, so far as we know, and is unaware of itself eternally reproducing itself. But in the human realm of freedom is the activity of man's creation, of his creating himself, consciously, in an image of truly free humanity, and in this process is man's nature itself transformed. Therefore do his political and social institution creations also change.

This creative activity of freedom is its own process; it is Werden, or developing or becoming, which is also the alchemical process which transforms otherwise inert, natural matter into social fabric. For example: fields are cultivated and maincained by means of labor and work; they are cleared of the excesses of natural growth which choke the 
progress of a natural necessity of life, 1.e., food. Minds which are culcivated, or liberated from the burdens of natural and bodily or even political necessity, are the minds of free men. They are also conscious of their freedom, that is their Gattungswesen, their "species" or "family being".

For Marx, this is a method of the present--past, present, future are not rigidly or causally related; the truth of the dialectical method, of history, is its internal relationships, which are never static, as the Utopians would believe. The language of freedom, i.e., ideology, is also part of the method, and tmparts by its self-consclous use an order to the phenomenon of historical movements, moments. (Reardon 1974 , Seminar notes) Language 1 tself is the mexcuric gift, kerygma, and is certainly not a rigid Iinear process; nature and history are not linear, or circular, but dialectical, and language, tool of the consciousness, reflects this fact and process.

True freedom, then, or the state of being (Wesen) truly free, must be considered the grand sum of many, variant component parts; it is itself a dialectical union of constituent relations and is productive of the "natural" freedom of (communistic) man, who is himself in a state of Werden. (011man 1971, p. 120) Necessity itself (Notwendigkeit) Is the basis of freedom; or, freedom as necessity, can be, is, realized as a society, as the nature of men in a 
comunistic state of being. (See Figure 1)

The social conditions-politics, religion, division

of labor, property, etc.-which determine the state of the individual's needs and powers, also determine or create those interests which the individual strives to satisfy; these same social conditions serve within nations and masses to separate and/or divide, thereby defining the boundaries between men, their class or caste, e.g., peasant, bourgeois, knight, Jew, proletarian. History is the process and the record, of the continuing and evolving movements of masses strugging in time and against and with each other. The relationships between mutually alienated classes are the "un-natural 1aws" of history, and by observing these laws, Marx can predict that the end of these un-natural conditions is in the evolution of communistic man. History as we know it, a long litany of wars and strife of nations and their classes, is ending precisely because of "inexhorable, utterly unembellishable, absolutely imperious need." (Marx 1962, p. 705) History is ended in the communistic Wesen, as the strife of classes and races, men and women of every race and all classes ceases, and individuals become the living free persons of the dreams of poets. They cease to be philosophical ideals (Goethe's marble statues), existing only in their brains, and become real human beings. Marx discloses his vision and himself as that of an heir to the searching question of the Enlightenment, to. 


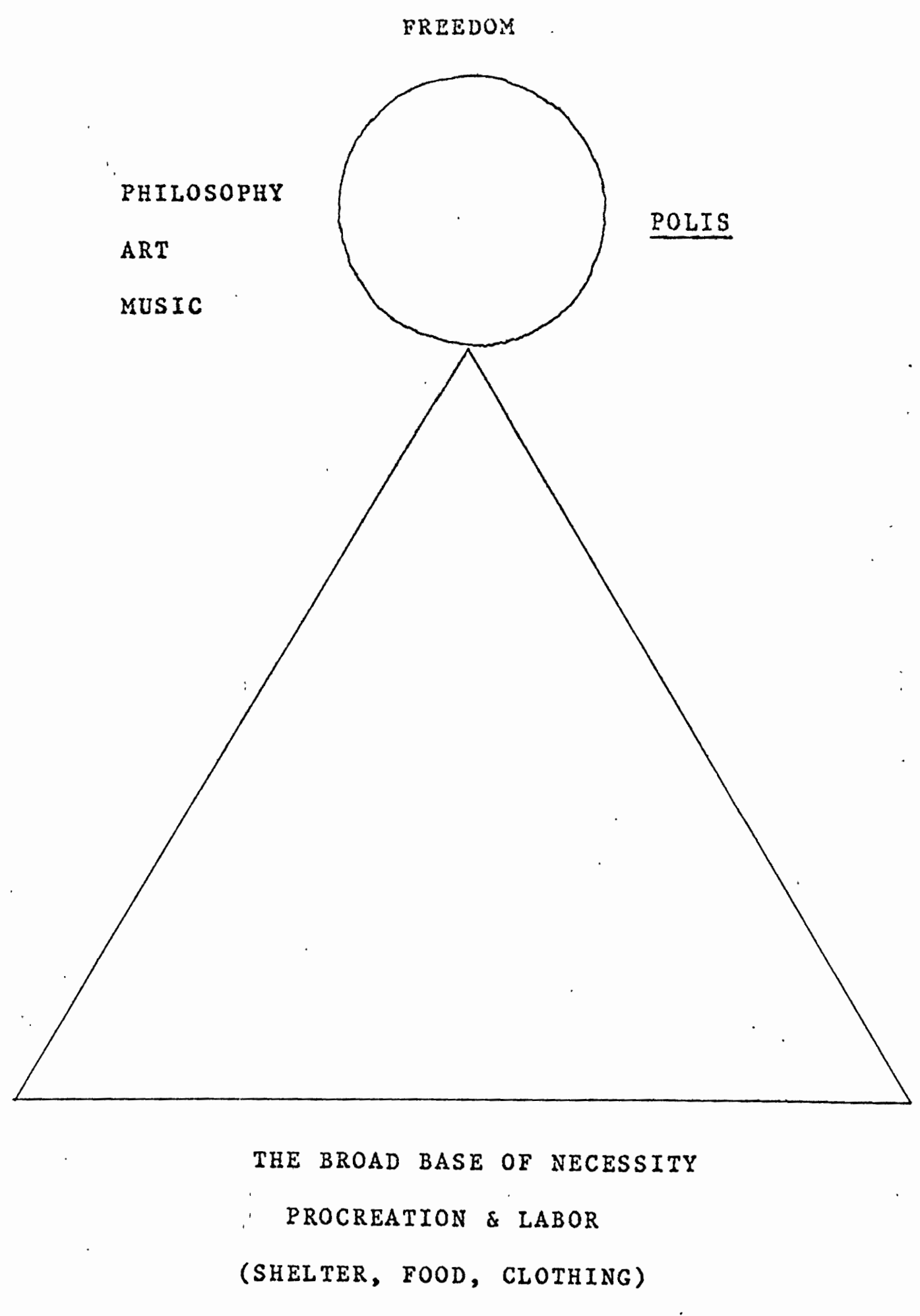


the pragmaticlsm of the French socialists Proudhon, SaintSimon, and as sibling of the Romantics' tenacious belief In the herolc freedom of individuals. Such is the nature of Allegemeinheit. "Die Freiheir ist nichts; zu werden frel ist das Hime1." (Feuerbach) 1

"Die Freiheit is dies; nichts zu wollen als sich." (Hegel) ${ }^{2}$ Consclousness and being are united by the power of necessity; by submitting to necessity, men display their natural state of "zu werden Exei". This submission increases the power of men within nature and necessity, and becomes'a source of freedom to them. Alienatedinecessity, which prevents a man from acting according to the dictates of "human" natural desires is no freedom; it is instead a compulsion, from without, and is contrary to human natural desires.

Communism, as the positive dissolution of private property, of human self-alienation (selbtsentfremdung), and thus as the real acquisition of human essence by and for mankind; therefore (communism) as whole, conscious, and within the entire wealth of existing development, has become the return of mankind to itself as society, i.e., as human being. (menschlichen Menschen)

This communism is, as perfected naturalism which equals humanism, as perfected humanism (vollendeter Humanismus) equals naturalism, the genuine solution to the confict between man and nature, the crue resolution of the quarrel between existence and essence (Wesen), between objective proof and self-conftrmation, between freedom (Ereiheit) and necessity (Notwendigkeit), between individual and species. It is the riddle of history, solved, and it knows itself as that solution. (Marx 1844, pp. 593-594; Tucker, p. 20) (author's transiation) (See Figure 2)

I"Freedom is nothing; to become free is Heaven." 2"Freedom is this; to will nothing as self." 


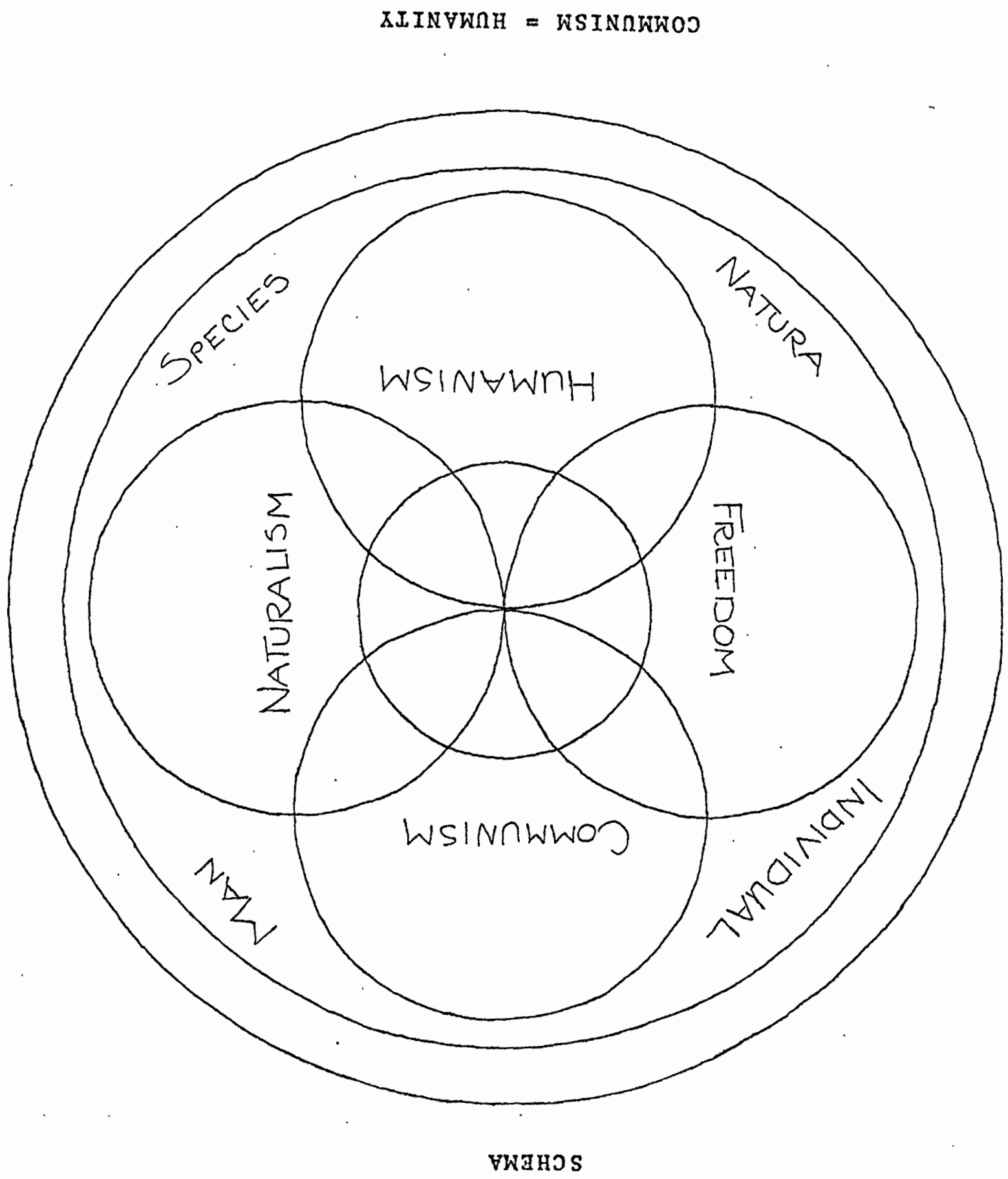




\section{FINALE: ALLEGRO MA NON TROPPO}

History and Literature. History as Literature. The textual scrutiny and critical analysis which are the cornexstones of the study of literature have been fmportant and profitable tools in the examination of Marx's histortcal and philosophlcal writing. The statement of Marc Bloch's to the effect that there is always a problem of impartiality has recurred many times to me; the word is equivocal. Perhaps history, or historical study, is less subject to this problem of interpretation than is literature per se, but it is nonetheless true that reading and understanding depend upon the various perceptual abilitfes, developments, quirks and tastes that the individual reader may bring to it. Since this is the case, even the reading of history becomes problematical.

The obvious advantage of "literature" as such is its self-sufficlency, its self-containment. A particular workform--epic, drama, or novel--is ultimately its own truth, as are other art-forms and works. In the experiencing of a poem or a novel, and in the analyzing of them also, we comprehend them as their own truth, a truth which itself is always in motion, and in the process of revealing itself. This 
process invites participation in the form that it assumes, or is, more correctly, given by its creator.

A process and phenomenon such as this is presented also by Karl Marx, and indeed the reader is invited to submit to and participate in this Werden. Marx has written history in such a way that it becomes a literary form which requires argument, examination, analysis. The chronology of his writing-olts images and metaphors of birth, growth, cultivation, architecture, etc--appears in the analysis as something starting indeed. One sees that Marx envisions in his pages a secularized millenarianism--the return to the garden, Heaven on earth. Human beings turn to themselves and to each other in a perfection of freedom which is, at its foundations, a humanistic catholicism; history, thus written and as we know it, tells of humanity turned and turning against itself. The end of human alienation is the ending also of history, is die blaue Blume found. What Is by necessity becoming history (Werden) is the communistic culmination and furtherance of mankind, which knows itself to be the solution to the riddle of history. This commuism "knows" Itself, because it is not an abstract,. It is mankind, communism is children, men, and women, and they are the answer to the famous riddle spoken to Oedipus. Marx advocates the necessarily voluntary taking-up of the polis, so that in the end humanity is crowned with the sweet roses of freedon, those very same roses with which 
Zarathustra crowns himself, free, at last, of the cross and the crown of thorns.

Marx writes of his belief that humanity is capable of the revolution and transformation which is communistic, $1 . e$. whole, free human beings. In this way Marx is a faithful man, humanist and romantic, who, in his own species, his own famlly-belng, sees the transformation of himself, and prophesies the confirmation of mankind into a new Weltanschauung, a new Being in the World.

There may be two truths which we, as historians and readers of literature, must recognize: These are the truths of history and the txuth in history. The truth in history (and 1iterature, too) is its reciprocal influence upon those who study it, write it, live it, et. al.; history in fact determines the historian as well as the historian decides certain things about history. The truth of history is its massiveness, its multitude of analyses, explanations, versions, facets of a thing which, an sich, may or may not be an object; let alone objective. It is; Lear cries in his madness, "no thing." If history is gratia history--how could it not be a curlous, dynamically mutable fusion of subject and object, of subjective and objective? The dual sense of history, the blend of personal and "objective" history, emerges here again, and varies in its forms. History leads us down many paths--now challenging, now encouraging philosophy, or cynicism, or romanticism, its opposite, 
the cynic's natural enemy. One is compelled by history; clio invokes our reflecting, she demands our understanding. She leads us, perhaps even tempts us to the truth in history. Which is, plainly enough, ourselves. By which is meant: ourselves and ourselves. Ourselves is the subject: the subject is the object of history. From Ourselves the sens of history is formed.

"Meaning" is one of the developments of history, or rather of historlcal understanding, and the meaning leads back inevitably to ourselves. Perhaps one is baffled by this, and must ask once more what we'are; we, like Hamlet, rust exclaim "What a piece of work is a man!" Here the craft of history ends, and the art begins.

History must finally be, in its sum, constituted of more than a formulated reiteration of events or sequences of events. A great deal of information and truth lie squarely within the mannex in which these events are related, and this is something which begs for constderation and analysis--for the possibilities of many forms and approaches. When we reconstitute the function of criticism, which transforms history from recollection into re-creation, we have participated in the art of history, which is that $\checkmark$ which provides us with a new concext, or, as Marx would. have it, with a new world. The memory of mankind is. not $v$ only a reconstructing of the culture of the past--that past, our collective humanistic history--is for us our 
buried life. The re-creation of history--which occasionally assumes all the proportions of the recognition scene of tragedy--is the discovery, or better, the recovery of the total form of our present life. The constant renewal of the world, and the subsequent engendering of moral phenomena which that renewal itself engenders, produces an abundance of levels to explore, to re-explore. The reader or writer of history, as a participant in history, as well as the poet or dramatist is obligated to "make it new". This is the process which must free us from habit, prejudlce, and indoctrination, if we are to understand aright.

It is useful to stay with hamlet a moment more: History, like the play, may appear to, but actually does not, present isolated blows of fate. All the characters, all the action, no matter how petty or sinister, are part of the play, and all of them together with the main event or character, form a polyphonic Gestalt which finds its order within itself. And like the play, which when acted upon and spoken, ceases to be Ifterature at 211 and becomes a re-creation of life, of Iiving, history is also a drama, comic or tragic, then absurd, infinitely rich, which finds its order within itself. "The rest is silence."

Therefore history, as an art as well as a sclence, has the function, and certainly the demand, to humanize us; it does this by giving, in its study, the depth of historical perspective. This does not happen 211 at once; it is 
a slow process within which the world of realities in which men strut and fret theix hour is changed, growing broader, richer in human possibilities. In a very important sense, history is literature, ard as Iiterature it is a structure made of words, of language. Language--and a11 structures built of words, as philosophy, history, theology, psychology, law-- Is built of the exact same myths and metaphors as those which are conventionally consigned to "literature"s? Polonius: "What are you reading?" Hamlet: "Words, words, words."

Certalnly history--like literature, as literature-has a descriptive and a constructive aspect. Two aspects, which are actualiy part of one process. The descriptive aspect establishes a representation or replica of external factors, and provides certain information about cultures and morés. The constructive aspect is and conveys a hypothesis or metaphor, and as we read or listen, we make the metaphorical or hypothetical identiflcation. The constructive aspect is fulfilled when we have become aware of and participated in the conceptualized or organized structural pattern or event. In short, we have become informed, and history, like drama and poetry, the great myths, has become a recreation of life. 


\section{SELECTED BIBLIOGRAPHY}

Arendt, Hannah, 1973. The Human Condition, University of Chicago Press, Chicago.

Arnold, Matthew. 1962. Lectures and Essays in Criticism, R. H. Super, Editor, Complete Prose Works of Matthew Arnold, Volume III, Ann Arbor: University of Michigan Press.

Avron, Henct. 1970. Marxist Aesthetics, translated by Helen Lane, Cornell University Press, Ithaca, London.

Baxandal1, Lee, and Stefan Morawski. 1973. Marx and Engels on Literature and Art, Telos Press, St. Louis, Missouri.

Bloch, Marc. 1953. The Historian's Craft, translated by Peter Putnam, Vintage Books, Random House, New York.

Bloom, Harold. 1970. Romanticism and Consciousness: Essays in Criticism, Yale University, W. W. Norton \& Co., Ine., New York.

Browne, Lewis, 1927. That Man Heine, Literary Guild of America, New York.

Butler, E. M. 1958. The Tyranny of Greece Over Germany, Beacon Press, Beacon Hill, Boston.

- 1968. The Saint-Simonian Religion in Germany, Howard Fertig, Inc., New York.

Feuchtwanger, E. J. 1974. Upheaval and Continuity, University of Pittsburg Press, Pittsburg.

Garoudy, Roger. 1970. Marxism in the Twentieth Century, translated by René Hague, Charles Scribner's Sons, New York.

Greenlaw, Ralph W. 1958. The Economic Oxigins of the French Revolution, D. C. Heath \& Co., Lexington, Massachusetts.

Heine, Heinrich. 1959. Religion and Philosophy in Germany, translated by John Snodgrass, Beacon Paperback, Boston.

Hermand, Jost. 1966. Das Junge Deutschland; Texte und Dokumente, Sturtgard Reclan, Seutegart. 
Hixth, Friedrich. 1951. Heinrich Heine: Briefe, Sechster Band, Flonau Kupterbere Verlag, Mainz.

Hoffmann und Campe. 1972. Heinrich Heine: 1979-1856, Herausgegeben von Rudolf Walter leonhardt, Hoffmann und Campe Verlag, Hamburg.

Jameson, Frederic. 1971. Marxismand Form, Princeton University Press, Princeton.

Krieger, Leonard. 1957. The German Idea of Freedom, Beacon Press, Boston.

Legge, J. G. 1970. Rhyme and Revolurion In Germany, Ams Press, New York.

Leland, Charles Godfrey. 1900. The Works of Heinrich Heine, translated by $C$. G. Leland, Volumes 9, 10 , 13, 16, Croscup and Sterling. Co., New York.

Iswith, Kar1. 1967. From Hegel to Nletzsche, translated by David $E$. Green, Anchor-Doubleday, New Lork.

Marcuse, Herbert. 1960. Reason and Revolution, Beacon Press, Boston.

Marx, Karl. 1962.. Früheschriften, Hans-Joachim Lieber and Peter Furth, Editors, Volumes I, II, CottaVerlag-Stuttgart.

1971. Grundisse, David Mcclellan, Editor and Translator, Haxper Torch Books, New York.

Mayer, Hans. 1973. "Heinrich Heine, German Ideology and Ideologists," New German Critique, No. 1, Winter, pp. 2-18.

McClellan, David. 1970. Marx Before Marxism, Harper \& Row, Wew York.

Mende, Fritz. 1970. Heinrich Helne: Chronik Seines Lebens und Werke, Akademie-Verlag, Berlin.

011man, Bertel1. 1971. Alienation, Cambridge University press, Cambidge.

Payne, Robert. 1971. The Unkrown Kar1 Marx, New York University Press, New York.

Reckham, Morse. 1965. Romanticism: The Culture of the Nineteenth Cencury, George Braziller, Inc., New York. 
Prawer, Siegbert. 1960. Heine: Buch der Lieder, Edward Arnold Publishers, Ltd., 41 Maddox Street, London, W.I.

1970. The Romantic Peitod in Germany, London Universicy institute of Germanic Studies, Schocken Books, New York.

Reardon, Michael F., Seminar notes, The origins and Development of Karl Marx's Thought, February, 1974.

Sagarra, Eda, and Herbert Tint. 1971. Tradition and Revolution: German Literature and Soctety 1830-1890, Basic Books, Inc.. New York.

Samons, Jeffrey L. 1969. Heinrich Heine: The Elusive Poet, Yale University Press, New Haven and London.

Schenk, H. G. 1966. The Mind of the European Romantics, Constable \& Co., Ltd., London.

Schwarzchild, Leopold. 1947. Karl Marx: The Red Pruss1an, translated by Margaret Wing, The Universal Library, Grosset \& Dunlap, New York.

Spargo, John. 1970. Karl Marx: His Life and Work, B. W. Huebsch, New York.

Sprigge, C. J. S. 1949. Karl Marx, Duckworth, 3 Henrietta Street, London.

Treitschke, L. 1919. History of Germany in the Nineteenth Century, translated by Eden and Cedar Paul, Volumes IV, V, VII, Jarrold \& Sons, Warwick Lane, G. Allen \& Unwin, Ltd., Museum Street, London.

Tucker, Robert C. 1972. The Marx-Engels Reader, Princeton University Press, W. W. Norton \& Co., Inc., New York.

Victor, Walther. 1970. Marx und Heine, Henschelverlag, Kunst und Gesellschaft, BerIIn. 
APPENDIX A

Translation, p. 49, Heine's Deutschland: Ein Wintermärchen

A new song, a betzer song,

o friends, will I compose for you:

Here on earth will we

Establish the heavenly kingdom.

On earth will we be happy,

Suffering no more want;

The idle stomach shall not squander nor

feast upon what diligent hands have earned.

Bread enough grows here on earth,

For all the children of men,

Roses and myrtle also, beautiful and joyous

And sweet green peas, no less.

Yes, sweet tiny peas for everyone,

Bursting from their pods!

We leave heaven

To the angels and the sparrows. 


\section{APPENDIX B}

Translation, p. 50, Heine:

I will my full right of freedom

I find the narrow limits;

And Paradise is changed

Into hell and chains. 


\section{APPENDIX C}

\section{Translation, p. 54, Heine:}

It reeked of blood, tobacco and schnaps And of hanged scoundrels as weil-Who smelled so foul in life, How fragrant must he be in death: 
APPENDIX D

p. 7: "Zur Judenfrage" (Marx)

p. 9: "Kritik der HegeIschen Rechtsphilosophie" (Marx) "

p. 17: "Deutsche Ideologie" (Marx)

p. 26: "Kritik der Hegelschen Rechtsphilosophie" (Marx)

p. 27: "Bäder von Iucca" (Heine)

p. 34-35: Iudwig Börne (Heine)

p. 39: "Über den Denunziaten" (Heine)

pp. 40-41: "Vershiedenartige Gesichtsaufassung," from Aux Armes Citoyens: (Heine)

pp. 42-43: "Französtschen Maler" (Heine, viz., Delacrolx" "Liberty Leading the People.")

p. 43: "Kritik der Hegelschen Rechtsphilosophie."

p. 52: "Verschiedenartige Gesichtsauffassung," (Heine)

P. 52: "Kxitik der Hegelschen Rechtsphilosophie" (Marx)

p. 55: "Zux,Judenfrage" (Marx)

pp. 57-58: Ietter of January I7, 1855, to Engels.

p. 58: "Revue des deux mondes," from Briefe über Deutschland (Heine)

pp. 59-60: Geständnisse (Heine)

Pp. 60-61: "Deutsche Ideologie" (Marx)

p. 62: "Die Heilige Familie" (Marx)

Pp. 63-64: "Die entrremde Arbett" from ökonomisch-ph110sophische Manuskripte, (Marx)

p. 64: "Kritik der Hegelschen Rechrsphilosophie" (Marx)

p. 66: "Deutsche Ideologie", borh quotes (Marx)

p.71: "Die Heilige Famille" (Marx)

p.71: "Prlvateigentum und Kommunismus," ökonomisch-philoso-: phishe Manuskripte (Marx) 